\title{
24. PLIOCENE AND PLEISTOCENE PALYNOSTRATIGRAPHY AT ODP SITES 646 AND 647, EASTERN AND SOUTHERN LABRADOR SEA ${ }^{1}$
}

\author{
Anne de Vernal ${ }^{2}$ and Peta J. Mudie ${ }^{3}$
}

\begin{abstract}
Pliocene and Pleistocene sediments from ODP Hole 647A in the south central Labrador Sea and Hole 646B off southwest Greenland were sampled at 1.5 -m intervals for studies of terrestrial and marine palynomorphs, including pollen, spores, dinocysts, and acritarchs. The dinocyst assemblages suggest that surface-water masses were cool-temperate to subarctic during most of the Pliocene and Pleistocene. The occurrence of a few warm-temperate indicators, notably Impagidinium species and Polyspaeridium zoharyi, suggests almost continuous northward advection of warm North Atlantic Drift into the Labrador Sea. A major decrease in dinocyst diversity and abundance marks the late Pliocene to early Pleistocene interval. The abundance of acritarchs in Pliocene sediments off southwest Greenland suggests high productivity, which may reflect nutrient flux from the shelf or upwelling; productivity appears to have been much lower at the central Labrador Sea site. Pollen and spore concentrations also decrease from the late Pliocene to early Pleistocene. This diminution probably reflects the impoverishment of vegetation and southward migration of the eastern Canadian tree line at the onset of climatic cooling and glaciation.
\end{abstract}

\section{INTRODUCTION}

During Leg 105, holes were drilled in Cenozoic sediments at two sites in the Labrador Sea (Fig. 1): (1) Site 647, located on the abyssal plain (water depth $=3862 \mathrm{~m}$ ) at the southern edge of the central Labrador Sea $\left(53^{\circ} 19.87^{\prime} \mathrm{N}, 45^{\circ} 15.72^{\prime} \mathrm{W}\right)$; and (2) Site 646 , on the continental rise (water depth $=3451 \mathrm{~m}$ ) off southwest Greenland $\left(58^{\circ} 12.56^{\prime} \mathrm{N}, 48^{\circ} 22.15^{\prime} \mathrm{W}\right)$. Drilling at these sites provided a unique opportunity to study the biostratigraphy and climatostratigraphy of the high-latitude northwest Atlantic in a region that has been strongly affected by the late Cenozoic glaciations. The first occurrence of ice-rafted debris, which indicates glacial activity, is dated at about 2.6-2.5 Ma at both Sites 646 and 647 (Srivastava, Arthur, et al., 1987), as recorded elsewhere in the North Atlantic (e.g., Backman, 1979; Shackleton et al., 1984; Eldholm, Thiede, et al., 1987).

Pliocene-Pleistocene sediments from Holes 647A and 646B were sampled at about $1.5-\mathrm{m}$ intervals for palynological analyses to provide a regional dinocyst and acritarch stratigraphy and to reconstruct changes that occurred in surface-water masses (dinocysts and acritarchs) and terrestrial vegetation (pollen and spores) as a result of the late Cenozonic cooling.

\section{METHODS}

Samples were prepared for palynological analysis using the following techniques.

1. Measuring the sample volume (usually between 5 and $10 \mathrm{~cm}^{3}$ ) by immersion in a graduated cylinder.

2. Spiking the sample with an aliquot volume $(1.00 \mathrm{~mL})$ of a calibrated suspension of Eucalyptus globulus pollen grains.

3. Sieving at 125 and $10 \mu \mathrm{m}$ with distilled water to eliminate coarse sand and gravel, fine silt, and clay particles;

4. Treating with cold $10 \% \mathrm{HCl}$ (until visible reaction ceases) to remove carbonates.

\footnotetext{
${ }^{1}$ Srivastava, S.P., Arthur, M., Clement, B., et al., 1989. Proc. ODP, Sci. Results, 105: College Station, TX (Ocean Drilling Program).

${ }^{2}$ Laboratoire de Géochimie Isotopique et de Géochronologie (GEOTOP), Université du Québec à Montréal, Case Postale 8888, Succursale "A," Montréal, Québec H3C 3P8, Canada.

${ }^{3}$ Geological Survey of Canada, Atlantic Geoscience Centre, P.O. Box 1006, Dartmouth, Nova Scotia B2Y 4A2, Canada.
}

5. Treating with repeated hot $52 \% \mathrm{HF}$ (1 to $12 \mathrm{hr}$ ) to dissolve silicate minerals.

6. Treating with hot $10 \% \mathrm{HCl}(15 \mathrm{~min})$ to eliminate fluorosilicates formed during the reaction with $\mathrm{HF}$.

7. Sieving at $10 \mu \mathrm{m}$ to clean the preparation.

8. Mounting the residual sample in glycerine gel on microscope slides.

This preparation method limits the losses that can result from strong chemical treatments, such as acetolysis (Mudie, 1980) or nitric acid treatment (de Vernal et al., 1983; Mudie, 1986). However, organic and mineral remains are often abundant. Thus, only a few samples were reprocessed to obtain clean specimens for photography. These samples were immersed in an ultrasonic bath for 30 to $60 \mathrm{~s}$ and then sieved at 20 $\mu \mathrm{m}$.

The palynomorph concentrations were calculated on the basis of the marker-grains method (Matthews, 1969). The Eucalyptus globulus suspension used for the source of marker grains was calibrated by several counts on a hemacytometer. This method is accurate to approximately $10 \%-12 \%$ for a 0.95 confidence interval (de Vernal et al., 1987).

The index to genera and species of Lentin and Williams (1985) was used as reference for the dinoflagellate cyst nomenclature. New cysts and other microplankton are described in the "Systematic Descriptions" section (this chapter).

\section{HOLE 646B}

During drilling at Site 646, an almost complete upper Miocene to Holocene sedimentary sequence was recovered. The Pliocene-Pleistocene interval is represented by approximately 484 $\mathrm{m}$ of sediment. This interval is characterized by apparently uniform sedimentation rates of 7.9 to $9.6 \mathrm{~cm} / \mathrm{k}$.y., averaging 9.0 $\mathrm{cm} / \mathrm{k}$.y. (Srivastava, Arthur, et al., 1987). Two main lithological units were distinguished.

1. Unit I (236.4-0 mbsf; $\sim 2.6-0 \mathrm{Ma})$ was defined by the presence of gravel and cobble originating from ice rafting. This unit is of late Pliocene to Holocene age. Sediments are predominantly grayish silty clays, clayey silts, and clayey muds. Terrigenous material dominates, with some intervals rich in biogenic carbonates and silicates. Deposits are mainly fine-grained, either homogeneous or bioturbated, and show little evidence of turbidites.

2. Unit II (766.7-236.4 mbsf; $\sim 8.5-2.6 \mathrm{Ma})$ is uniform and consists mainly of bioturbated gray silty clays and clays of late 


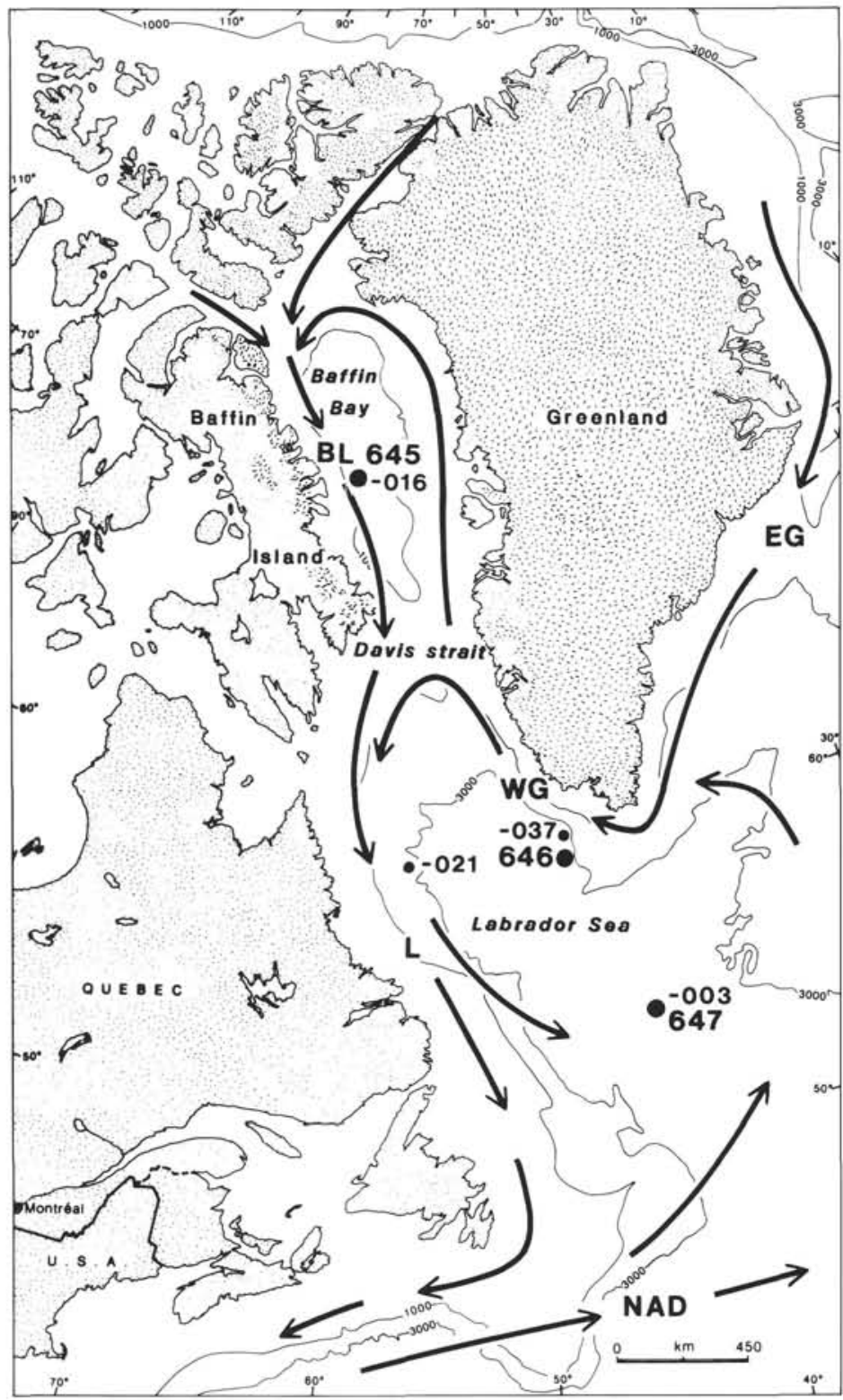

Figure 1. Location map of ODP Sites 645,646 , and 647 and of site survey piston cores. The modern surface-water circulation is indicated by arrows: $\mathrm{NAD}=$ North Atlantic Drift; EG $=$ East Greenland Current; WG $=$ West Greenland Current; $\mathrm{L}=$ Labrador Current; and $\mathrm{BL}=$ Baffin Land Current.

Miocene to late Pliocene age. No evidence of turbidite sedimentation exists.

Recovery of Pliocene-Pleistocene sediments was $61 \%$. Because of this poor core recovery, the magnetostratigraphic data do not provide a continuous time control. Thus, the chronostratigraphic framework depends strongly on biostratigraphic data, notably planktonic foraminifers and calcareous nannofossils. Berggren et al.'s time scale (1985) is used here and is defined mainly by the planktonic foraminifer stratigraphy (Srivastava, Arthur, et al., 1987). However, the early-late Pleistocene boundary corresponds to the Brunhes/Matuyama magnetic reversal recorded at 59 mbsf.

Palynomorphs were analyzed and counted in 155 samples from core-catcher samples and core sections above 484 mbsf (lower Pliocene to Holocene sediments) at Hole 646B. The palynological results are compiled in Table 1 and summarized in Fig- ure 2. Additional high-resolution (20-cm sampling intervals) palynological studies of upper Pleistocene sediments at Site 646 are reported by Aksu et al. (this volume).

\section{Marine Palynoflora}

\section{Dinocyst and Acritarch Stratigraphy}

The assemblage composition of the marine palynoflora varies considerably through the Pliocene-Pleistocene sequence drilled at Site 646 (Fig. 3). Note that several taxa characteristic of the Pliocene interval have not been reported previously in the literature. In addition, acritarchs that are rarely included in Neogene palynostratigraphies constitute a large part of the Pliocene marine palynoflora. Based on the acme occurrences of the most common taxa, five assemblage intervals can be defined as follows. 
Table 1. Palynomorph concentrations in analyzed samples from Hole 646B.

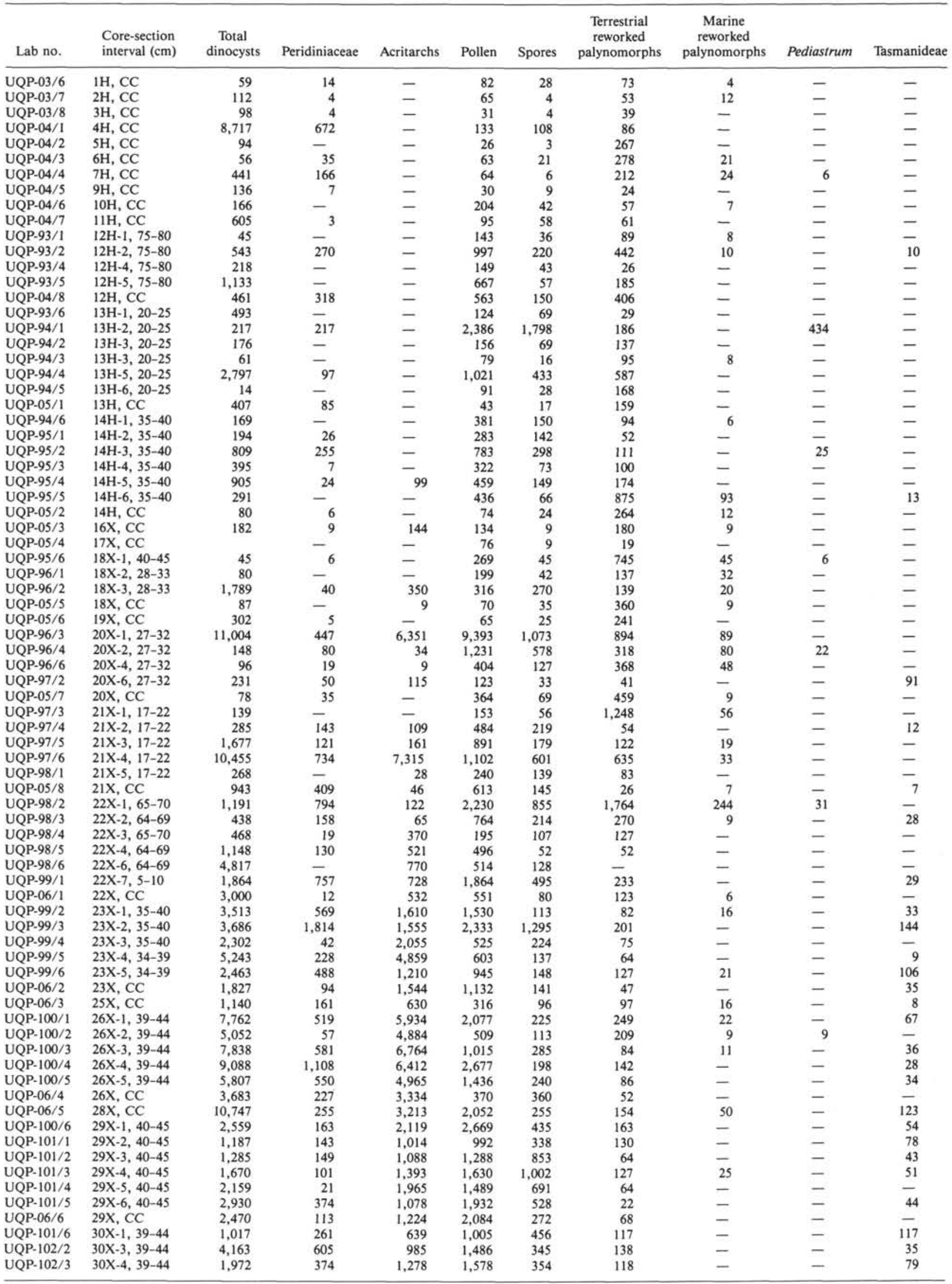


Table 1 (continued).

\begin{tabular}{|c|c|c|c|c|c|c|c|c|c|c|}
\hline Lab no. & $\begin{array}{l}\text { Core-section } \\
\text { interval }(\mathrm{cm})\end{array}$ & $\begin{array}{c}\text { Total } \\
\text { dinocysts }\end{array}$ & Peridiniaceae & Acritarchs & Pollen & Spores & $\begin{array}{l}\text { Terrestrial } \\
\text { reworked } \\
\text { palynomorphs }\end{array}$ & $\begin{array}{c}\text { Marine } \\
\text { reworked } \\
\text { palynomorphs }\end{array}$ & Pediastrum & Tasmanideae \\
\hline UQP-102/4 & $30 X-5,39-44$ & 1,231 & 215 & 873 & 1,117 & 501 & 71 & - & - & - \\
\hline UQP-06/7 & $30 \mathrm{X}, \mathrm{CC}$ & 2,615 & 1,383 & 1,153 & 1,518 & 672 & 376 & 16 & - & 16 \\
\hline UQP-108/2 & $31 X-1,27-32$ & 2,451 & 480 & 1,173 & 2,185 & 640 & 80 & $\bar{c}$ & - & 53 \\
\hline UQP-108/3 & $31 X-2,27-32$ & 5,733 & 800 & 2,867 & 2,221 & 671 & 232 & 26 & - & 129 \\
\hline UQP-108/4 & $31 X-3,27-32$ & 5.450 & 406 & 2,944 & 3,284 & 812 & 177 & 34 & - & 203 \\
\hline UQP-108/6 & $31 X-4,27-32$ & 7,629 & 494 & 2,166 & 3,301 & 494 & 190 & - & - & 152 \\
\hline UQP-108/6 & $31 X-5,27-32$ & 1,140 & 209 & 835 & 610 & 225 & 144 & 16 & - & - \\
\hline UQP-06/8 & $31 \mathrm{X}, \mathrm{CC}$ & 3,080 & 373 & 1,291 & 1,412 & 252 & 171 & - & - & 31 \\
\hline UQP-110/2 & $32 X-1,18-23$ & 4,139 & 772 & 2,941 & 1,447 & 331 & 436 & 36 & - & 181 \\
\hline UQP-110/4 & $32 X-3,18-23$ & 6,041 & 1,326 & 4,272 & 3,487 & 1,572 & 147 & - & - & - \\
\hline UQP-110/6 & $32 X-5,18-23$ & 1,703 & 700 & 880 & 1,783 & 180 & 60 & 20 & - & - \\
\hline UQP-111/1 & $32 X-6,18-23$ & 2,919 & 321 & 2,321 & 1,769 & 574 & 138 & - & - & 22 \\
\hline UQP-07/1 & $32 \mathrm{X}, \mathrm{CC}$ & 1,535 & 642 & 791 & 1,459 & 493 & 224 & - & - & - \\
\hline UQP-111/2 & $33 \mathrm{X}-1,25-30$ & 5,374 & 432 & 4,572 & 2,095 & 205 & 477 & 67 & 22 & - \\
\hline UQP-111/3 & $33 X-2,25-30$ & 6,915 & 234 & 6,188 & 1,803 & 858 & 260 & - & - & 26 \\
\hline UQP-111/4 & $33 \mathrm{X}-3,25-30$ & 2,851 & 106 & 2,652 & 635 & 412 & 42 & - & - & 11 \\
\hline UQP-111/5 & $33 X-4,25-30$ & 17,458 & 456 & 16,742 & 1,401 & 1,008 & 24 & - & - & - \\
\hline UQP-111/6 & $33 \mathrm{X}-5,25-30$ & 14,560 & 593 & 13,727 & 2,992 & 1,928 & 89 & - & - & - \\
\hline UQP-07/2 & $33 \mathrm{X}, \mathrm{CC}$ & 3,022 & 109 & 2,761 & 490 & 77 & 122 & - & - & - \\
\hline UQP-07/3 & $34 \mathrm{X}, \mathrm{CC}$ & 7,920 & 1,241 & 2,547 & 2,482 & 514 & 300 & 21 & - & 86 \\
\hline UQP-112/1 & $35 \mathrm{X}-1,22-28$ & 4,815 & 485 & 2,207 & 2,994 & 703 & 97 & - & - & 24 \\
\hline UQP-112/2 & $35 \mathrm{X}-2,22-28$ & 1,370 & 279 & 804 & 281 & 234 & 67 & - & - & - \\
\hline UQP-112/3 & $36 \mathrm{X}-1,82-87$ & 4,822 & 417 & 2,169 & 1,169 & 626 & 125 & 21 & - & 43 \\
\hline UQP-112/4 & $36 X-2,71-76$ & 5,064 & 216 & 1,458 & 685 & 216 & 198 & - & - & 18 \\
\hline UQP-112/5 & $36 \mathrm{X}-3,8-13$ & 6,090 & 1,251 & 1,467 & 1,644 & 645 & 172 & 129 & - & 43 \\
\hline UQP-112/6 & $36 \mathrm{X}-4,53-55$ & 1,156 & 366 & 405 & 1,194 & 656 & 115 & - & - & - \\
\hline UQP-113/2 & $36 \mathrm{X}-5,8-13$ & 1,586 & 579 & 406 & 1,487 & 792 & 19 & - & - & 38 \\
\hline UQP-113/4 & $36 \mathrm{X}-6,114-119$ & 1,549 & 351 & 198 & 998 & 824 & 61 & - & - & - \\
\hline UQP-07/4 & $36 \mathrm{X}, \mathrm{CC}$ & 1,746 & 140 & 60 & 160 & 60 & 80 & - & - & - \\
\hline UQP-114/1 & $37 X-1,30-35$ & 3,258 & 65 & 1,404 & 509 & 359 & 49 & - & - & 49 \\
\hline UQP-114/3 & $37 X-3,30-35$ & 2,940 & 136 & 833 & 734 & 170 & - & 17 & - & 34 \\
\hline UQP-114/4 & $37 X-4,30-35$ & 3,854 & 118 & 3,066 & 1,217 & 280 & 59 & - & - & 29 \\
\hline UQP-114/5 & $37 X-5,30-35$ & 10,747 & 201 & 10,496 & 451 & 100 & - & - & - & - \\
\hline UQP-115/1 & $37 X-7,30-35$ & 4,888 & 24 & 2,856 & 1,050 & 288 & 48 & - & - & 48 \\
\hline UQP-115/2 & $38 \mathrm{X}-1,58-61$ & 5,684 & 96 & 1,290 & 828 & 135 & 77 & - & - & 96 \\
\hline UQP-115/4 & $38 X-3,53-56$ & 2,129 & 294 & 1,404 & 883 & 272 & 45 & - & - & - \\
\hline UQP-115/5 & $38 \mathrm{X}-4,58-61$ & 1,707 & 162 & 675 & 1,724 & 513 & 81 & - & - & 54 \\
\hline UQP-116/1 & $38 \mathrm{X}-6,55-58$ & 1,961 & 175 & 1,229 & 833 & 137 & 39 & - & - & 39 \\
\hline UQP-07/6 & $38 \mathrm{X}, \mathrm{CC}$ & 584 & 47 & 374 & 498 & 259 & 86 & - & - & - \\
\hline UQP-116/2 & $39 \mathrm{X}-1,19-24$ & 8.968 & 400 & 4.108 & 1,772 & 396 & - & - & - & 41 \\
\hline UQP-116/3 & $39 \mathrm{X}-2,19-24$ & 17,637 & 153 & 5,956 & 2,376 & 333 & 77 & - & - & 25 \\
\hline UQP-116/4 & $39 X-3,19-24$ & 20,384 & 31 & 11,067 & 822 & 806 & 62 & - & 31 & - \\
\hline UQP-116/5 & $39 X-4,19-24$ & 32,966 & 651 & 11,072 & 1,866 & 690 & 51 & 51 & - & 77 \\
\hline UQP-116/6 & $39 X-5,19-24$ & 15,982 & 150 & 5,160 & 2,237 & 437 & 72 & - & - & - \\
\hline UQP-117/1 & $39 \mathrm{X}-6,19-24$ & 6,220 & 167 & 2,296 & 1,169 & 334 & 84 & - & - & 42 \\
\hline UQP-07/7 & $39 \mathrm{X}, \mathrm{CC}$ & 2,812 & 82 & 1,078 & 817 & 278 & 16 & - & - & - \\
\hline UQP-117/2 & $40 X-1,21-26$ & 12,149 & 123 & 2,518 & 1,109 & 260 & 260 & - & - & 26 \\
\hline UQP-117/3 & $40 X-2,12-16$ & 22,273 & 200 & 8.267 & 1,850 & 389 & 266 & - & - & 82 \\
\hline UQP-117/4 & $40 X-3,21-26$ & 13,472 & 50 & 5,666 & 1,058 & 334 & 167 & - & - & 56 \\
\hline UQP-117/5 & $40 X-4,21-26$ & 16,137 & 58 & 7,661 & 2,242 & 815 & 29 & - & - & 29 \\
\hline UQP-118/1 & $40 X-6,21-26$ & 20,597 & 92 & 6,495 & 3,897 & 1,206 & 92 & - & - & 92 \\
\hline UQP-118/3 & $41 X-2,26-30$ & 9,626 & 250 & 3,865 & 1,825 & 286 & - & - & - & 250 \\
\hline UQP-118/4 & $41 X-3,27-31$ & 9,805 & 429 & 2,683 & 1,564 & 268 & 161 & - & - & 54 \\
\hline UQP-118/5 & $41 X-4,27-31$ & 5,111 & 185 & 1,549 & 696 & 84 & 101 & - & - & 17 \\
\hline UQP-118/6 & $41 X-5,27-31$ & 7,150 & 276 & 2,300 & 863 & 230 & 23 & - & - & - \\
\hline UQP-119/1 & $41 X-6,27-31$ & 7,870 & 247 & 2,793 & 1,432 & 437 & 112 & - & - & 19 \\
\hline UQP-08/1 & $41 \mathrm{X}, \mathrm{CC}$ & 3,383 & 85 & 1,117 & 423 & 101 & 51 & - & - & $\overline{-}$ \\
\hline UQP-119/2 & $42 X-1,16-21$ & 10,420 & 75 & 6,385 & 977 & 275 & 100 & - & - & 20 \\
\hline UQP-119/3 & $42 X-2,9-14$ & 8,805 & 102 & 4,572 & 2,172 & 1,118 & 127 & - & 25 & 25 \\
\hline UQP-119/4 & $42 X-3,9-14$ & 3,444 & 271 & 1,899 & 730 & 355 & 63 & - & - & 21 \\
\hline UQP-119/5 & $42 X-4,9-14$ & 5,979 & 118 & 2,295 & 717 & 118 & 134 & - & - & 34 \\
\hline UQP-119/6 & $42 X-5,8-14$ & 9,300 & 266 & 2,398 & 1,066 & 506 & 53 & - & - & 106 \\
\hline UQP-120/1 & $42 X-6,17-22$ & 2,600 & 119 & 739 & 787 & 429 & 72 & - & - & - \\
\hline UQP-08/2 & $42 \mathrm{X}, \mathrm{CC}$ & 3,418 & 1,386 & 531 & 1,006 & 132 & 94 & 19 & - & 37 \\
\hline UQP-120/2 & $43 X-3,111-116$ & 9,959 & 30 & 4,949 & 1,131 & 763 & 91 & - & - & 30 \\
\hline UQP-08/3 & $43 \mathrm{X}, \mathrm{CC}$ & 4,326 & 473 & 1,072 & 491 & 127 & 55 & 18 & - & 18 \\
\hline UQP-08/4 & $44 \mathrm{X}, \mathrm{CC}$ & 2,863 & 553 & 1,259 & 582 & 57 & 57 & - & - & - \\
\hline UQP-08/5 & $45 \mathrm{X}, \mathrm{CC}$ & 4,717 & 80 & 4,029 & 704 & 144 & 48 & - & - & - \\
\hline UQP-120/3 & $46 \mathrm{X}-2,64-67$ & 6,398 & 232 & 4,630 & 1,328 & 181 & 90 & - & - & - \\
\hline UQP-08/6 & $46 \mathrm{X}, \mathrm{CC}$ & 720 & 20 & 300 & 90 & 38 & 9 & - & - & - \\
\hline UQP-08/7 & $47 \mathrm{X}, \mathrm{CC}$ & 2,631 & 54 & 2,509 & 177 & 68 & 81 & 13 & - & - \\
\hline UQP-08/8 & $48 \mathrm{X}, \mathrm{CC}$ & 1,701 & 169 & 543 & 241 & 12 & 24 & - & - & - \\
\hline UQP-120/4 & $49 X-2,64-67$ & 6,548 & 20 & 2,666 & 868 & 197 & 79 & - & - & - \\
\hline UQP-09/1 & $49 \mathrm{X}, \mathrm{CC}$ & 3,143 & 66 & 2,081 & 136 & 44 & - & - & - & - \\
\hline UQP-120/5 & $50 X-1,72-77$ & 5,559 & 34 & 5,352 & 1,167 & 720 & 34 & - & $\overline{-}$ & $\overline{-}$ \\
\hline UQP-120/6 & $50 \times-3,0-5$ & 3,177 & 46 & 1,832 & 186 & 231 & 232 & 23 & 23 & 23 \\
\hline UQP-09/2 & $50 \mathrm{X}, \mathrm{CC}$ & 1,061 & 37 & 689 & 223 & 73 & 73 & 37 & - & - \\
\hline
\end{tabular}

Note: Total dynocysts include dinoflagellate cysts and acritarchs. 


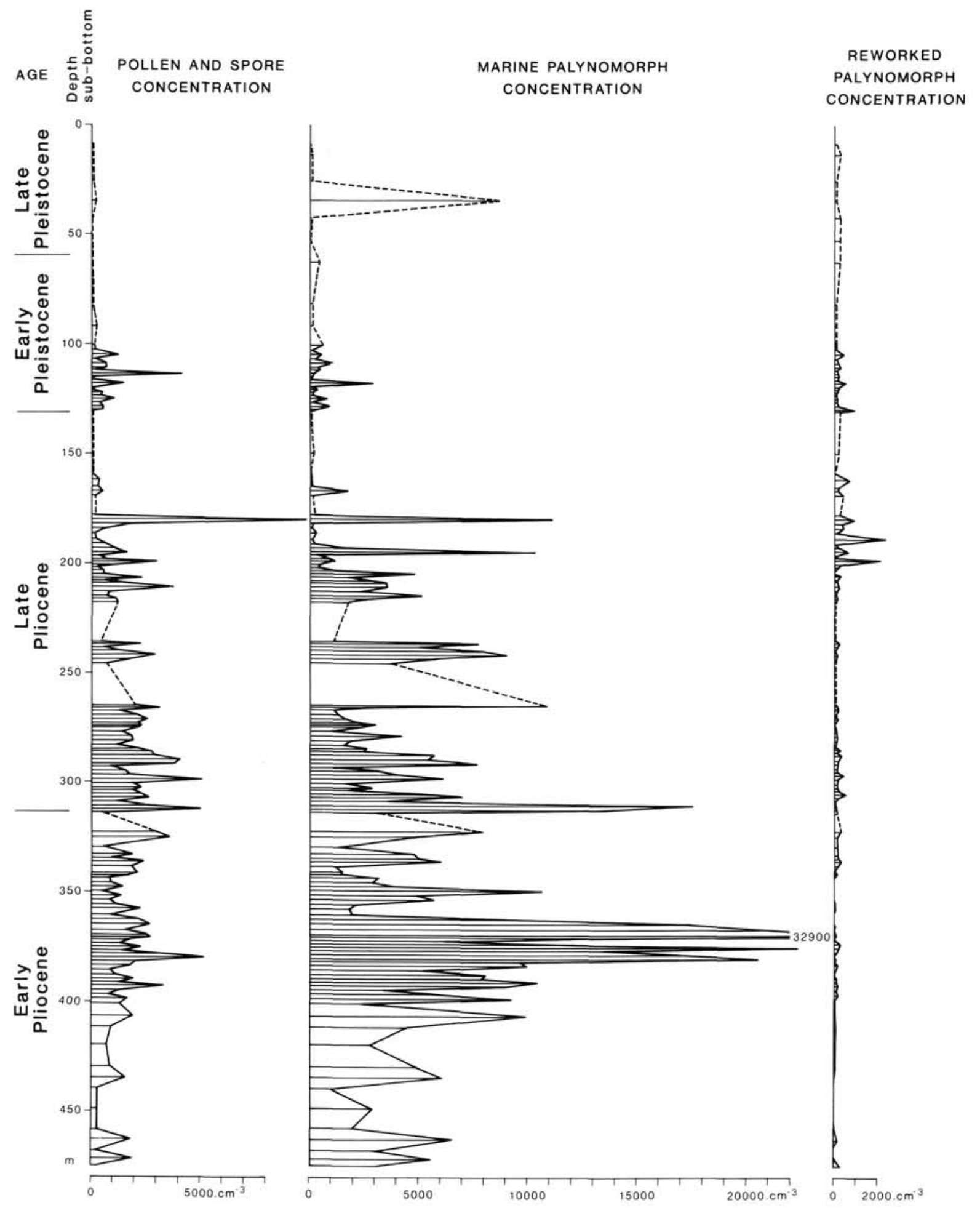

Figure 2. Palynomorph concentrations vs. depth at Hole 646B. Marine palynomorphs include dinocysts and acritarchs. In the text, we frequently refer to common or abundant occurrence of taxa, which correspond to concentrations of $100-1000 \mathrm{cysts} / \mathrm{cm}^{3}$ and $>1000$ cysts $/ \mathrm{cm}^{3}$, respectively.

1. Interval V (484-435 mbsf; $\sim 5.4-4.8 \mathrm{Ma})$; relatively low taxonomic diversity characterizes this interval, which is of probable earliest Pliocene age. Brigantedinium sp., Nematosphaeropsis labyrinthea, Filisphaera filifera, Cymatiosphaera sp. I, and Batiacasphaera sphaerica constitute the dominant taxa.

2. Interval IV (435-361 mbsf; $\sim 4.8-4.0 \mathrm{Ma})$, this early Pliocene interval is defined by the stratigraphic range and abun- dance of cyst type I. The assemblages are dominated by this unusual cyst-form, along with Cymatiosphaera sp. I, Brigantedinium sp., Nematosphaeropsis labyrinthea, Filisphaera filifera, Corrudinium sp. I, and Batiacasphaera sphaerica, which are all common to abundant in most samples. Operculodinium crassum and Operculodinium longispinigerum also are present in most samples. This assemblage interval contains the highest tax- 


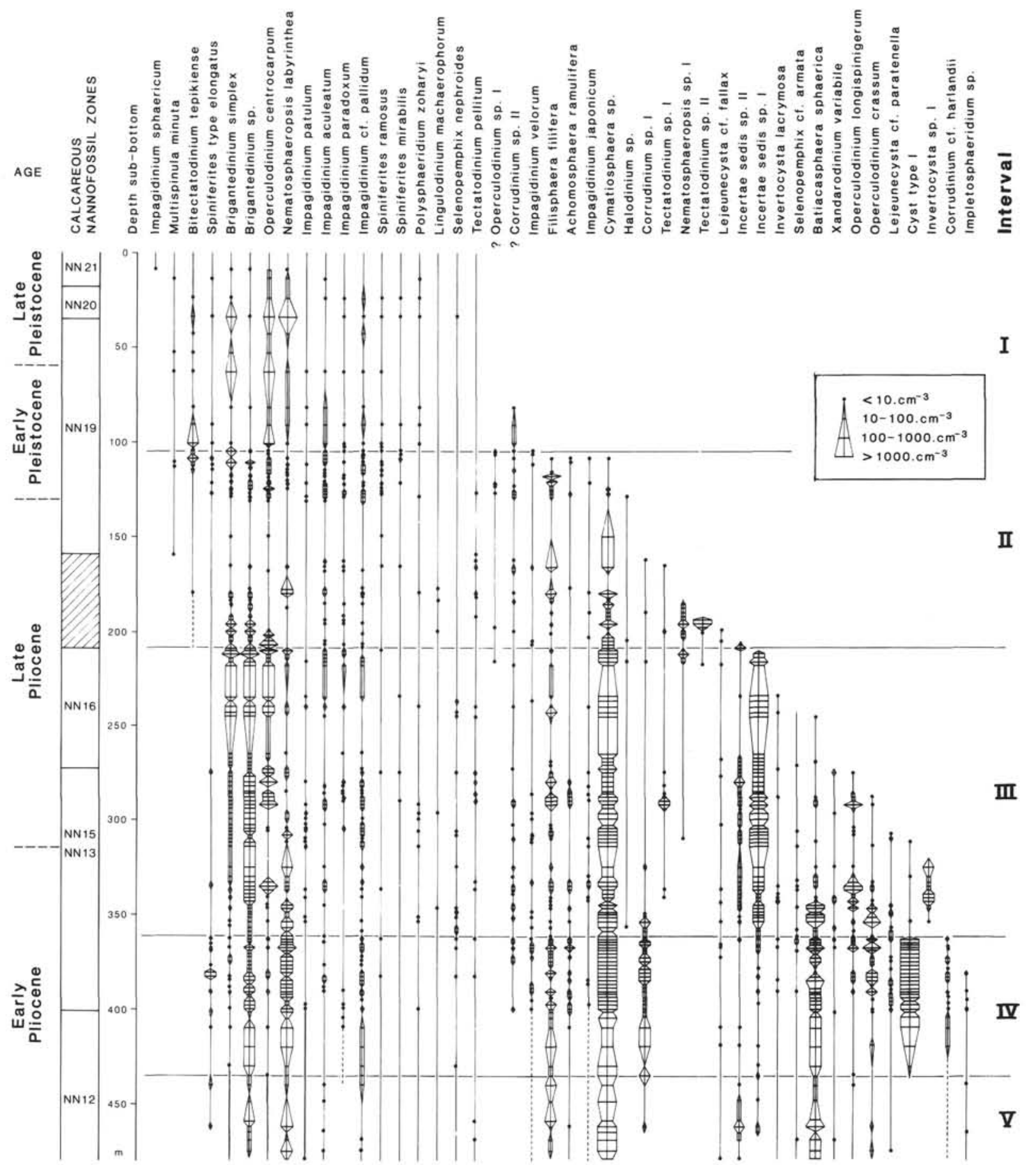

Figure 3. Stratigraphic range of dinoflagellate cysts and acritarchs in Pliocene-Pleistocene sediments of Site 646.

onomic diversity and concentrations observed in the PliocenePleistocene sequence of Site 646.

3. Interval III (361-209 mbsf; $\sim 4.0-2.3 \mathrm{Ma})$; this interval covers the early-late Pliocene transition, which is distinguished by common-to-abundant acritarchs, referred to here as Incertae sedis I, that belong to the Pterospermopsis subgroup of Downie (1973). The acritarchs Cymatiosphaera sp. I and Incertae sedis I dominate the assemblages, accompanied by the dinocysts Brigantedinium simplex, Filisphaera filifera, Nematosphaeropsis labyrinthea, and Operculodinium centrocarpum. The lower part of the interval is characterized by the last common occur- rences of Corrudinium sp. I, Batiacasphaera sphaerica, Operculodinium longispinigerum and Operculodinium crassum. The base of the interval also is marked by the occurrence of Invertocysta sp. I, which has a restricted stratigraphic range at Site 646.

4. Interval II (209-105 mbsf; $\sim 236-123 \mathrm{Ma})$ this interval includes the upper Pliocene and the lowest Pleistocene. The top of interval II is distinguished by the last occurrence of several taxa, notably Filisphaera filifera and Cymatiosphaera sp. I, which dominate the upper Pliocene assemblages. The common occurrence of Nematosphaeropsis sp. I and Tectatodinium sp. II marks the base of this zone. 
5. Interval I (105-0 mbsf; $\sim 1.2-0 \mathrm{Ma})$; the top interval includes most of the Pleistocene and it is essentially characterized by dinocyst species that are common in modern marine sediments of the Labrador Sea, e.g., Operculodinium centrocarpum, Nematosphaeropsis labyrinthea, and Brigantedinium simplex (Mudie, 1980; de Vernal, 1986; de Vernal and Hillaire-Marcel, 1987a, 1987b). The last appearance of ?Corrudinium sp. II occurs near the base of this interval ( $~ 82 \mathrm{mbsf}$ ).

Except for Interval V, the diversity and abundance of dinocysts and acritarchs at Site 646 decreases gradually from the early Pliocene to the early Pleistocene. However, an abrupt disappearance of seven taxa marks the Interval II/I transition, which is early Pleistocene in age.

\section{Paleoenvironmental Interpretation}

Large fluctuations in the total abundance of marine palynomorphs occur throughout the Pliocene-Pleistocene interval: concentrations vary from 0 to 32,900 cysts $/ \mathrm{cm}^{3}$, with the amplitude generally increasing uphole. Assuming uniform sedimentation rates, these changes in concentrations of up to five orders of magnitude must reflect fluctuations in production of dinocysts and acritarchs influxes that, to some extent, reflect fluctuations in the phytoplankton productivity. Most modern dinocysts correspond to a dormant stage in the life cycle of motile dinoflagellates (e.g., Wall and Dale, 1968). Not all dinoflagellate genera produce fossilizable sporopollenin cysts, and the number of cysts does not always reflect the size of the motile-stage plankton (Dale, 1976, 1983). Thus, the dinocyst assemblages provide only a fragmentary picture of the dinoflagellate populations, but an overall correlation between total annual phytoplankton population size and cyst production does exist. A few prasinophytes also produce sporopollenin phycoma that are represented by Pterosphermopsis-group cysts, notably the acritarch Cymatiosphaera. Dinocysts and prasinophyte cysts constitute meroplanktonic populations that are approximate indicators of phytoplankton productivity.

The intervals V to III, which include most of the Pliocene $(\sim 5.4$ to $2.3 \mathrm{Ma})$, are characterized by high marine palynomorph concentrations $\left(>2000 / \mathrm{cm}^{3}\right)$, which indicates a high primary productivity. However, in these intervals concentrations show fluctuations of two orders of magnitude, which may correspond to productivity cycles, changes in sedimentation rates and processes, or both. In intervals II and I ( $\sim 2.3$ to $0 \mathrm{Ma})$, the average cyst concentration is less than $1000 / \mathrm{cm}^{3}$, which suggests a trend of decreasing productivity from Pliocene to Pleistocene. The amplitude of cyclical variations in concentrations also increases in parts of this interval (Fig. 2).

High-resolution studies of the upper Pleistocene sediments at Site 646 (Aksu et al., this volume) and other Labrador Sea locations (Cores 84-030-021, 84-030-003, and HU-75-037; de Vernal and Hillaire-Marcel, 1987a, 1987b) reveal important fluctuations in dinocyst concentrations that directly correlate with the $\delta^{18} \mathrm{O}$ stratigraphy: the rich assemblages occur in interglacial stages, while the low concentrations mark glacial episodes. At Site 646, the strong diminution in marine palynomorph concentrations recorded at the base of interval II $(\sim 2.3 \mathrm{Ma})$ occurs slightly above the first ice-rafted deposit $(\sim 2.6 \mathrm{Ma})$. The late Pliocene decrease in dinocyst concentrations, interpreted in terms of reduced productivity, seems related to the initiation of glaciations at high latitudes.

Despite large variations in their taxonomic diversity and composition, the dinocyst assemblages are predominantly boreal in character throughout the Pliocene-Pleistocene. The exact environmental affinities of many dinocyst species are presently unknown. However, the dominant components of Site 646 assemblages are found most commonly in Neogene and modern sediments of high-latitude regions, such as Bering Sea and North
Pacific (Bujak, 1984), western North Pacific (Matsuoka, 1983), central and eastern North Atlantic (Mudie, 1986; Harland, 1979) and Norwegian Sea (Mudie, 1988). In addition, the co-occurrence of Operculodinium centrocarpum and Nematosphaeropsis labyrinthea, which dominate modern dinocyst assemblages of the Labrador Sea (de Vernal, 1986; de Vernal and HillaireMarcel, 1987a), suggests boreal cool-temperate to subarctic conditions in surface waters. The presence of the subarctic Spiniferites elongatus species complex (Harland et al., 1980) also indicates boreal to subpolar waters. Filisphaera filifera, a species found in Pliocene sediments of the Arctic Ocean (Aksu and Mudie, 1985; Mudie, 1985) and Bering Sea (Bujak, 1984), is another indicator of cool water masses. During most of the Pliocene-Pleistocene, cool-temperate to subarctic conditions probably prevailed in the surface waters of the eastern Labrador Sea. However, notable occurrences of warm-temperate to subtropical taxa (Impagidinium aculeatum, I. patulum, Spiniferites mirabilis; e.g., Harland, 1983; Turon, 1984), indicate a southern influence and suggest an almost continuous penetration of the North Atlantic Drift into the eastern Labrador Sea.

The abundance of acritarchs (Cymatiosphaera sp. I and Incertae sedis I) in the Pliocene deposits may indicate a high primary productivity. Cymatiosphaera and similar morphotypes, e.g., Incertae sedis I, are resting cysts of prasinophytes (Boalch and Parke, 1971) which are generally associated with nearshore environments (Tappan, 1980). In the Quaternary fossil record, Cymatiosphaera has been reported exclusively from neritic or epicontinental marine environments, such as the Ariake Sea (Takahashi, 1971) and the Black Sea (Wall et al., 1973). In studies of Paleozoic sediments (al-Ameri, 1986), acritarchs with a Pterospermopsis-type of wall (as in Cymatiosphaera and Incertae sedis I and II) are produced in the outer neritic zones where the water depth is about $100-200 \mathrm{~m}$. The abundance of acritarchs in Pliocene sediments from Site 646 therefore may reflect influx of neritic sediments, with subsequently enhanced primary productivity. Similarly, the common presence of peridinioid cysts (Brigantedinium spp., Lejeunecysta spp., and Selenopemphix spp.) and tasmanides, which are often associated with neritic-type environments (e.g., Tappan, 1980), also suggests influxes from the shelf. Alternatively, increased production of peridinioid cysts may be associated with upwelling conditions in oceanic environments (Wall et al., 1977; Matsuoka, 1985; Stein and Duffield, 1985). Abundant Pterospermopsistype acritarchs also are commonly associated with diatom-rich sediments at DSDP Sites 607 and 611 from the North Atlantic (Mudie, 1986) and in the Norwegian Sea (Mudie, 1988), where they appear to reflect nutrient upwelling in a pelagic environment.

\section{Terrestrial Palynoflora}

Pollen and spores are common to abundant throughout the lower Pliocene to lower Pleistocene sedimentary sequence of Site 646 (Fig. 2), with concentrations of 500 to $5000 / \mathrm{cm}^{3}$ in most samples. Counts of more than 100 pollen and spores in several samples are reported in the percentage diagram illustrated in Figure 4. The diversity of the pollen and spore assemblages is low, as normally found in oceanic sediments because of aerodynamic or hydrodynamic selection during transportation. Pinus pollen grains, which have a saccate morphology favorable to long-distance atmospheric and hydrologic transport, are particularly over-represented in deep-sea sediments off eastern Canada (Mudie, 1980, 1982; Heusser, 1983). Pinus is the dominant taxon of the pollen assemblages at Site 646, accompanied mainly by Picea, Betula, Tsuga, Lycopodium, Sphagnum, and Polypodiaceae.

Despite fluctuations in percentages, the taxonomic composition of the pollen and spore assemblages is relatively uniform 


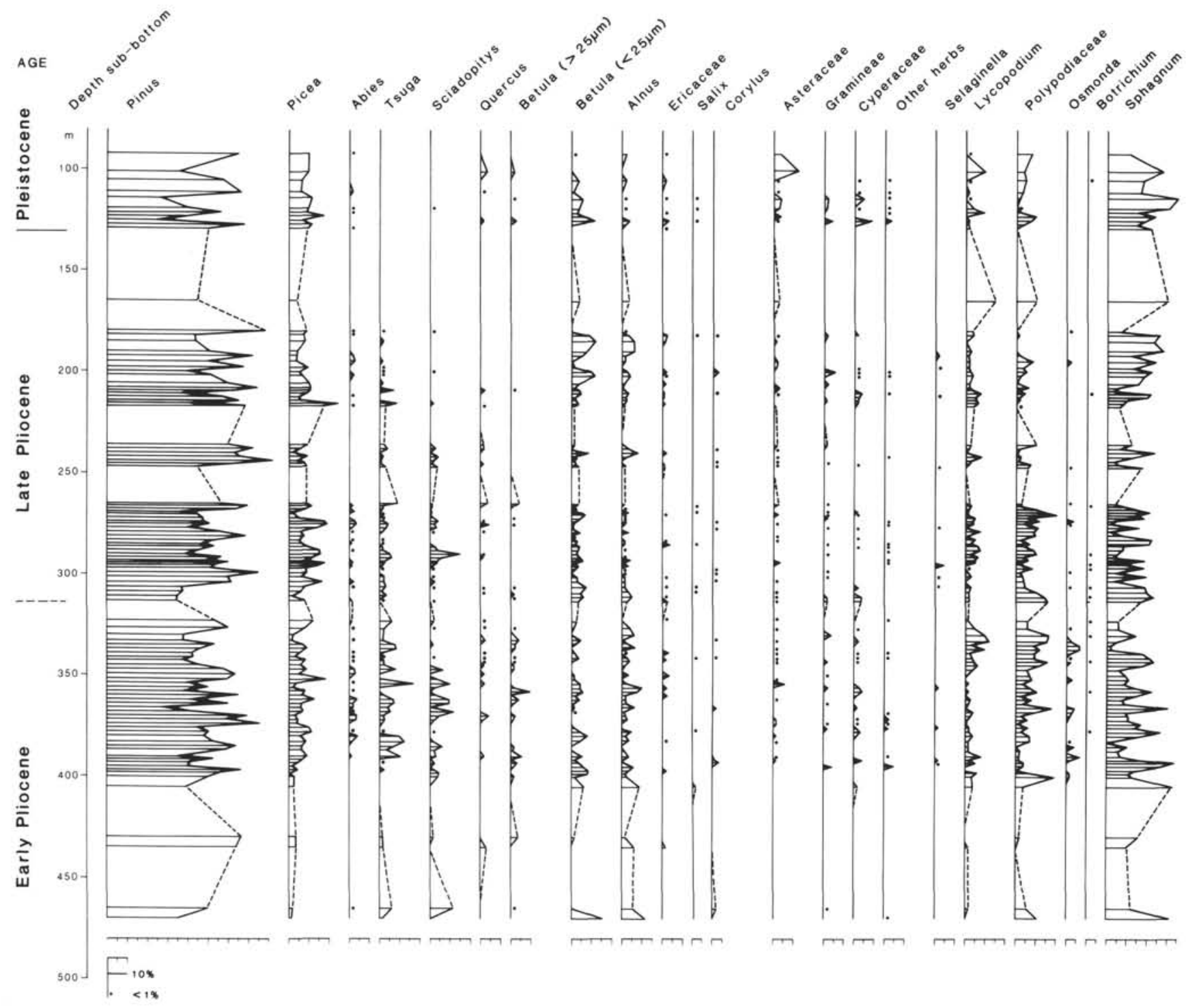

Figure 4. Summary diagram of pollen and spore percentages at Site 646 . These percentages are based on sums that include all the pollen grains and spores counted. The spectra reported here consist of sums higher than 100 individuals in most cases; spectra with sums lower than 50 individuals are not reported. Because of the low diversity, 100 individuals may be considered statistically representative (Mudie, 1982). The genus Betula is subdivided into two categories on the basis of pollen grain dimension: pollen grains with a diameter of less than $25 \mu \mathrm{m}$ probably represent shrub species, while larger grains are from tree taxa (Richard, 1970; Usinger, 1975). Several taxa are grouped into genera or families to simplify the results: Lycopodium spores include mainly $L$. annotinum, L. selago-type, and $L$. clavatum-type; the most common Asteraceae are Artemisia and undifferentiated Tubuliflorae; other herbs include mainly Polygonaceae, Cruciferae, Caryophyllaceae, and Chenopodiaceae pollen grains; Alnus is mainly represented by $A$. crispa, although $A$. rugosa sometimes was seen. The other taxa are grouped into genera because of the uncertainty of the species identification. Several taxa observed rarely are not reported in the diagram: notably Ulmus, Fraxinus, Carya, Ostrya, and Nemopanthus.

throughout the Pliocene-Pleistocene sequence. The only taxon with a limited stratigraphic range is Sciadopitys, which is restricted to Pliocene sediments. Tsuga, which is occasionally observed in Pleistocene sediments (Aksu et al., this volume), is also relatively abundant in the Pliocene sequence.

The pollen and spore assemblages show a boreal character, as indicated by the dominance of Picea, Betula, Alnus, Sphagnum, and Lycopodiaceae. By comparison with the modern distribution of pollen and spores in marine sediments off eastern North America, the assemblages at Site 646 suggest influxes ranging from mixed forest with boreal characteristics to open boreal forest or even shrub tundra (Mudie, 1982; Heusser, 1983). Thus, the terrestrial flora indicates the existence of humid cool- temperate to subarctic climatic conditions in the source areas. Decreasing percentages of temperate trees, notably Tsuga, Sciadopitys, Betula, and Quercus, are recorded in the upper Pliocene sediments, which suggests a change in the dominant vegetational source from a cool-temperate mixed forest to a more boreal vegetation. The decreasing pollen concentrations also suggest reduced influxes, probably from an impoverishment of the vegetation cover.

Pollen and spores reach marine sediments by multiple pathways (e.g., Mudie, 1982); therefore, the source area is often difficult to determine with certainty. Influxes of pollen and spores depend strongly upon transportation by atmospheric and/or oceanic circulation. Nevertheless, comparison of the continental 
palynostratigraphy with the upper Pleistocene stratigraphy at Site 646 (Aksu et al., this volume) and at nearby core sites (HU 75-37; de Vernal ad Hillaire-Marcel, 1986) reveals pollen influxes from southeastern Canada, mainly controlled by southwest-northeast or west-southwest/east-northeast atmospheric transportation. Assuming pollen influxes dominated by aerial transportation throughout the Pliocene-Pleistocene and atmospheric trajectories similar to those of today, the pollen diagram for Site 646 (Fig. 4) should reflect the vegetational changes over southeastern Canada. Such an interpretation is probably oversimplified because the atmospheric paleocirculation pattern cannot be assumed to have been uniform during the Pliocene-Pleistocene interval. In addition, the possibility of significant influxes from Greenland and through the Greenland current cannot be totally discounted. Despite these difficulties in interpretation, it seems clear that the palynostratigraphy at Site 646 indicates boreal, cool-temperate, and subarctic conditions around the Labrador Sea throughout most of Pliocene and early Pleistocene. A significant impoverishment of the vegetation, probably from global cooling, is evident for the latest Pliocene-earliest Pleistocene interval.

\section{Reworked Palynoflora}

Reworked palynomorphs were observed in most of the samples from Site 646. These consist mainly of trilete spores, notably Cicatricosisporites and Appendisporites, and bisaccate pollen grains. These terrestrial palynomorphs are characterized by a high degree of compression and a brownish color. Reworked acritarchs and dinocysts also are present: Veryhachium, Deflandrea spp., and Wetzeliellaceae are the most common taxa. The recognizable reworked palynomorph assemblages reflect the erosion of Paleogene and older strata, although reworked younger material also may be present. The reworked palynomorphs are most abundant in the upper $210 \mathrm{~m}$ of sediments. This may be attributed to increased erosion caused by continental glaciations and fluctuations in relative sea levels. The occurrence of icerafted debris in this interval also is indicative of glacial activity.

\section{HOLE 647A}

The sediments drilled at Site 647 include large unconformities (Srivastava, Arthur, et al., 1987), with a sharp contact between mottled olive-yellow silty clays and gray silty muds that separates upper Miocene from upper Pliocene sediments at about 116 mbsf. The upper Pliocene to Holocene sediments (110-0 mbsf; $\sim 2.5-0 \mathrm{Ma}$ ) constitute lithologic Unit I, which consists of interbedded gray to brownish-gray silty clay, clayey mud, and clayey silts that contain variable amounts of biogenic carbonates and ice-rafted debris. Silts, sands, and detrital carbonates are common in the uppermost $60 \mathrm{~m}$, which corresponds to the Pleistocene according to the planktonic foraminifer stratigraphy. Sedimentation rates at Site 647 are uniform and average 4.5 $\mathrm{cm} / \mathrm{k}$.y. for the Pliocene-Pleistocene sequence (Srivastava, Arthur, et al., 1987) and about $4.7 \mathrm{~cm} / \mathrm{k} . \mathrm{y}$. during the late Pleistocene (site survey Core 84-030-003; de Vernal and Hillaire-Marcel, 1987b).

The recovery of Pliocene-Pleistocene sediments by rotary drilling in Hole $647 \mathrm{~A}$ was about $64 \%$, providing an almost complete section for the 2.5-0 Ma time interval. The Pliocene/ Pleistocene boundary is located at about $58 \mathrm{mbsf}$, according to the planktonic foraminifer stratigraphy (Srivastava, Arthur, et al., 1987). The early/late Pleistocene boundary corresponds to the Brunhes/Matuyama magnetic reversal recorded at $35 \mathrm{mbsf}$ (Srivastava, Arthur, et al., 1987).

Palynomorphs were studied in 51 samples from core sections and from core-catcher samples of Site 647. Expressed in terms of concentrations, the results are summarized in Figure 5 and Table 2.

\section{Marine Palynoflora}

\section{Dinocyst and Acritarch Stratigraphy}

The taxonomic composition of the marine palynoflora varies significantly from the late Pliocene to late Pleistocene at Site 647 (Fig. 6). Two main assemblage intervals can be distinguished.

1. Interval II (116-50 mbsf; 2.5-1.1 Ma); this upper Pliocene to lower Pleistocene interval is marked by the occurrence of several taxa, in addition to the extant taxa that characterize interval I. The most common species in interval II are Filisphaera filifera, Cymatiosphaera sp. I, and Corrudinium sp. I.

2. Interval I (50-0 mbsf; $\sim 1.1-0 \mathrm{Ma}$ ); this Pleistocene interval is almost exclusively characterized by dinocysts, which are common in modern marine sediments of the region (Mudie, 1980; Mudie and Short, 1985; de Vernal, 1986). We do not consider the rare occurrence of the extinct species, Impagidinium velorum and $I$. japonicum, significant in this interval since only one specimen of each species was observed. The assemblages are dominated by Nematosphaeropsis labyrinthea, Operculodinium centrocarpum, Bitectatodinium tepikiense, Impagidinium aculeatum, I. cf. pallidum, I. paradoxum, and I. patulum. The only species that is restricted to this interval is Impagidinium sphaericum.

As at Site 646, the interval II/I transition, which marks the beginning of the early Pleistocene, is characterized by a significant decrease in dinocyst species diversity.

\section{Paleoenvironmental Interpretation}

The concentrations of marine palynomorphs (dinocysts and acritarchs) in the Pliocene-Pleistocene sediments of Site 647 are relatively low and average $500 \mathrm{cysts} / \mathrm{cm}^{3}$. Extrapolated from sedimentation rates, the corresponding influxes $\left(\sim 2.5 \mathrm{cyst} / \mathrm{cm}^{2}\right.$ / yr) suggest a low local dinoflagellate productivity. This may be caused by the offshore location of Site 647 , which lies in a midocean gyre and probably receives the limited influx of organic nutrients required for dinoflagellate metabolism (e.g., Margalef, 1978; Harland, 1983). In addition, dinoflagellate reproduction by excystment of dinocysts deposited on the abyssal seafloor is most improbable. Thecate-stage dinoflagellates were recorded from station Bravo near the drill site (Holmes, 1956); however, a large part of the dinocyst flux over the abyssal plain may be due to lateral oceanic transport (de Vernal, 1986; de Vernal and Hillaire-Marcel, 1987a, 1987b). Warm-temperate to subtropical (Impagidinium aculeatum, I. patulum, Lingulodinium machaerophorum, Spiniferites mirabilis; e.g., Harland, 1983), low salinity (Brigantedinium simplex; Mudie and Short, 1985) and arctic to subarctic (Multispinula minuta, Spiniferites elongatus; Harland et al., 1980) taxa occur together in most of the dinocyst assemblages at Site 647. Thus, multiple influxes from the Gulf Stream, North Atlantic Drift, and Labrador Current, must be considered. The notable occurrence of warm-water species indicates a penetration of temperate North Atlantic Drift water into the Labrador Sea throughout most of the late Pliocene to Holocene interval. However, the dominance of Filisphaera filifera (Bujak, 1984) suggests cool-temperate to subarctic conditions. The occurrence of common Brigantedinium simplex, which may be associated with low salinity conditions $(<30 \%$; Mudie and Short, 1985), is noticeable in lower Pleistocene sediments. In the upper Pliocene sediments, particularly between about 85 and 116 mbsf, the dominance of acritarch cysts (Cymatiosphaera sp. I) also suggests an influx from neritic areas.

\section{Terrestrial Palynoflora}

The terrestrial palynomorph concentrations vary considerably throughout the Pliocene-Pleistocene sequence, which sug- 


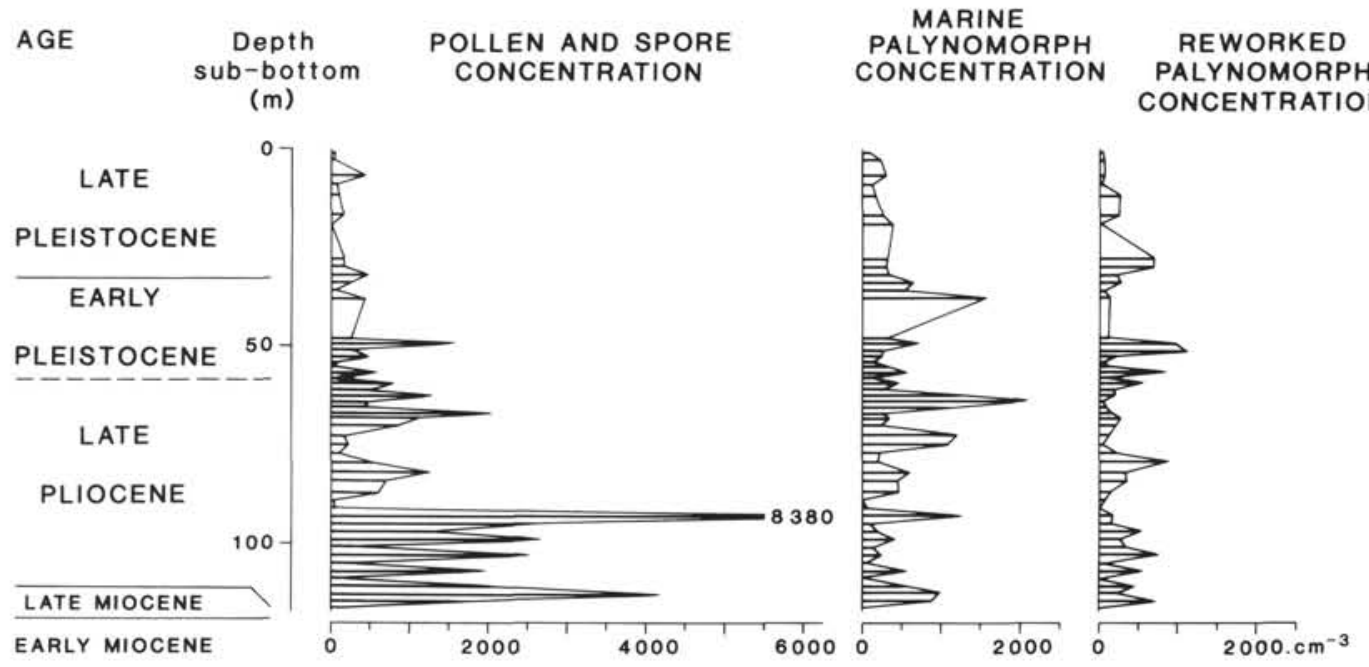

Figure 5. Palynomorph concentrations vs. depth at Hole 647A.

gests changes in the influx volumes and the extent of vegetation sources. Pollen and spore assemblages are similar in composition to those at Site 646 , with influxes from boreal coniferous forest vegetation during most of the interval (Fig. 7). In Pliocene sediments, the assemblages are dominated largely by Pinus, Picea, and Sphagnum, suggesting the prevalence of relatively dense coniferous forests and humid cool-temperate to subarctic climatic conditions in the source areas. These source areas would have been primarily in southeastern Canada, if influxes were mainly from southwest-northeast atmospheric circulation similar to that of today. The latest Pliocene and early Pleistocene interval also is marked by relatively high percentages of Quercus and Betula, which suggests influxes from a temperate mixed forest. Low pollen concentrations in the upper Pleistocene sediments and the limited number of samples prevent detailed interpretation. However, the decrease in pollen concentrations and the diminution of Quercus percentages in the upper Pleistocene sediments probably indicate an impoverishment of the vegetation that reflects long-term climatic cooling in eastern Canada.

\section{DISCUSSION OF THE ACRITARCH AND DINOCYST STRATIGRAPHY}

Our knowledge of the geographical distribution and stratigraphic range of Neogene dinoflagellate cysts is still fragmentary, especially for the high latitudes of the Northern Hemisphere. Studies conducted during the last decade have significantly increased the data base for high-latitude Neogene palynostratigraphy, notably reports by Manum (1976: Norwegian Sea), Harland (1979: Bay of Biscay; 1984: Goban Spur), Edwards (1984: Rockall Plateau), Bujak (1984: Bering Sea), Matsuoka (1983: central Japan), Mudie (1986: central North Atlantic) Mudie (1988: Norwegian Sea); Aksu and Mudie (1985: Arctic Ocean). Most of these studies led to the description of new dinoflagellate cyst species and erection of dinocyst zonations. Some "regionalism" seems to characterize all the above dinoflagellate stratigraphies. This probably reflects the relationship between fossil dinoflagellate assemblages and paleoenvironmental conditions in different high-latitude ocean basins. The modern distribution of dinocysts on the ocean floor is closely related to environmental parameters such as surface-water temperature and salinity (e.g., Wall, 1971; Wall et al., 1977; Harland, 1983; Turon, 1984), especially in high-latitude regions (Mudie and Short, 1985; Harland et al., 1980). Therefore, it is not surprising to find that the Pliocene-Pleistocene palynoflora in the Lab- rador Sea differs from those at other North Atlantic sites and that to date it cannot be correlated directly with other zonations.

In the Pliocene-Pleistocene dinocyst assemblages of Sites 646 and 647, several taxa occur throughout most of the sequence, notably Operculodinium centrocarpum, Nematosphaeropsis labyrinthea, and Brigantedinium simplex. These taxa have a wide geographical distribution in the Atlantic Ocean and occur in modern sediments from temperate to circum-Arctic areas. These opportunistic taxa appear to tolerate a wide range of temperature and salinity conditions, which also may explain their long stratigraphic range, especially in high-latitude regions of the Northern Hemisphere, where strong climatic fluctuations took place during the late Cenozoic.

In the Labrador Sea, several taxa have their last appearances in the upper Pliocene and lower Pleistocene sediments. The last appearance of Filisphaera filifera in the lowermost Pleistocene deposits at both Sites 646 and 647 is approximately synchronous with that of other boreal areas, such as the central North Atlantic (Mudie, 1986), eastern Norwegian Sea (Mudie, 1988), Bering Sea, and northern North Pacific (Bujak, 1984). Filisphaera filifera seems to have been an ubiquitous boreal species until the early Pleistocene and thus constitutes a good stratigraphic marker for northern high latitudes. Several other taxa that range into the early Pleistocene in the North Atlantic and North Pacific have their last appearance in Pliocene sediments of the Labrador Sea. These dinocysts are Operculodinium crassum, Operculodinium longispinigerum, Corrudinium harlandii, and Xandarodinium variabile. Their early disappearance in the Labrador Sea may reflect harsher environmental conditions because of the greater influence of arctic overflow water, compared to other boreal regions of the North Atlantic and North Pacific oceans. In contrast, Impagidinium cf. pallidum occurs throughout the Pliocene to Holocene interval in the Labrador Sea, while the morphologically similar species Impagidinium pallidum occurs only to the earliest Pleistocene in the North Pacific (Bujak, 1984) and Arctic oceans (Aksu and Mudie, 1985). Impagidinium cf. pallidum appears to be a form adapted to subpolar conditions: it is abundant in surface sediments on the Barents Shelf slope in the eastern Arctic (Mudie and Matthiessen, 1988).

Several other dinocysts that are abundant in Labrador Sea Pliocene sediments appear to have ranges that may be useful from a biostratigraphic viewpoint: these taxa are Batiacasphaera sphaerica, Invertocysta sp. I (Fig. 8), cyst type I, and Corrudinium $\mathrm{sp}$. I, which have relatively narrow ranges in lower Plio- 
Table 2. Palynomorph concentrations in analyzed samples from Hole 647A.

\begin{tabular}{|c|c|c|c|c|c|c|c|c|c|c|}
\hline Lab no. & $\begin{array}{l}\text { Core-section } \\
\text { interval }(\mathrm{cm})\end{array}$ & $\begin{array}{c}\text { Total } \\
\text { dinocysts }\end{array}$ & Peridiniaceae & Acritarchs & Pollen & Spores & $\begin{array}{c}\text { Terrestrial } \\
\text { reworked } \\
\text { palynomorphs }\end{array}$ & $\begin{array}{c}\text { Marine } \\
\text { reworked } \\
\text { palynomorphs }\end{array}$ & Pediastrum & Tasmanideae \\
\hline UQP-33/5 & IR-1, 58-64 & 94 & - & - & 31 & 9 & 47 & - & - & - \\
\hline UQP-33/6 & $1 R-2,63-69$ & 235 & - & - & 15 & 5 & 61 & 2 & 2 & - \\
\hline UQP-33/7 & $1 R-6,82-88$ & 300 & 63 & - & 389 & 63 & 90 & 5 & 5 & - \\
\hline UQP-12/8 & $1 \mathrm{R}, \mathrm{CC}$ & 113 & - & - & 35 & 39 & 37 & 2 & - & - \\
\hline UQP-33/8 & $2 \mathrm{R}-1,7-12$ & 160 & - & - & 100 & 8 & 200 & 12 & - & - \\
\hline UQP-34/1 & $2 R-6,33-39$ & 241 & 20 & - & 126 & 47 & 232 & 12 & - & - \\
\hline UQP-13/1 & $2 \mathrm{R}, \mathrm{CC}$ & 296 & - & - & 10 & - & 5 & - & - & - \\
\hline UQP-34/2 & $4 \mathrm{R}-1,92-96$ & 467 & 14 & - & 252 & 98 & 235 & 11 & 11 & 4 \\
\hline UQP-34/3 & $4 \mathrm{R}-2,69-74$ & 162 & 33 & - & 138 & 24 & 687 & 24 & - & - \\
\hline UQP-34/4 & $4 R-3,36-41$ & 337 & 32 & - & 332 & 124 & 192 & 24 & 5 & - \\
\hline UQP-34/5 & $4 R-4,43-48$ & 634 & 160 & - & 194 & 47 & 246 & 33 & 5 & - \\
\hline UQP-34/7 & $4 R-6,84-89$ & 575 & - & - & 40 & 13 & 23 & 8 & - & - \\
\hline UQP-13/2 & $4 \mathrm{R}, \mathrm{CC}$ & 1,669 & 1,364 & - & 375 & 31 & 118 & 16 & - & - \\
\hline UQP-13/3 & $5 \mathrm{R}, \mathrm{CC}$ & 299 & 102 & - & 173 & 85 & 105 & - & - & - \\
\hline UQP-35/1 & $6 \mathrm{R}-1,43-48$ & 689 & 634 & - & 1,392 & 717 & 952 & 13 & 55 & - \\
\hline UQP-35/2 & $6 R-2,43-48$ & 242 & 37 & - & 188 & 82 & 988 & 121 & - & - \\
\hline UQP-35/3 & $6 R-3,43-48$ & 228 & - & - & 306 & 118 & 196 & - & - & - \\
\hline UQP-35/4 & $6 R-4,43-48$ & 149 & - & - & 48 & 5 & 77 & - & - & - \\
\hline UQP-35/5 & $6 R-5,43-48$ & 330 & - & - & 23 & 10 & 75 & - & - & - \\
\hline UQP-35/6 & $6 R-6,43-48$ & 541 & 11 & - & 260 & 55 & 779 & 33 & - & - \\
\hline UQP-13/4 & $6 \mathrm{R}, \mathrm{CC}$ & 104 & - & - & 19 & 19 & 67 & 9 & - & - \\
\hline UQP-36/1 & $7 R-1,3-8$ & 426 & 9 & - & 725 & 64 & 526 & 55 & - & - \\
\hline UQP-36/2 & $7 R-2,3-8$ & 282 & 20 & - & 393 & 111 & 182 & 30 & - & - \\
\hline UQP-36/3 & $7 R-3,3-8$ & 1,285 & 470 & - & 770 & 450 & 211 & - & - & - \\
\hline UQP-36/4 & $7 R-4,3-8$ & 2,070 & 98 & - & 306 & 108 & 39 & - & - & - \\
\hline UQP-36/5 & 7R-5, 3-8 & 915 & 58 & - & 282 & 117 & 87 & 10 & - & - \\
\hline UQP-36/6 & $7 \mathrm{R}-6,3-8$ & 283 & 85 & 9 & 1,502 & 548 & 171 & 9 & 18 & - \\
\hline UQP-13/5 & $7 \mathrm{R}, \mathrm{CC}$ & 357 & 105 & 7 & 783 & 273 & 273 & 21 & 14 & - \\
\hline UQP-37/1 & $8 \mathrm{R}-1,21-26$ & 274 & 18 & - & 526 & 156 & 187 & 9 & - & - \\
\hline UQP-37/2 & $8 R-2,21-26$ & 1,179 & - & - & 108 & 36 & 115 & - & - & - \\
\hline UQP-37/3 & $8 R-3,21-26$ & 1,088 & - & - & 168 & 58 & 39 & - & - & - \\
\hline UQP-13/6 & $8 \mathrm{R}, \mathrm{CC}$ & 217 & - & - & 124 & 12 & 221 & - & - & - \\
\hline UQP-37/4 & $9 \mathrm{R}-1,15-20$ & 194 & - & - & 417 & 136 & 680 & 165 & 9 & - \\
\hline UQP-37/5 & $9 \mathrm{R}-2,15-20$ & 631 & - & 305 & 878 & 364 & 336 & 18 & - & - \\
\hline UQP-37/6 & $9 \mathrm{R}-3,15-20$ & 359 & - & 39 & 538 & 161 & 341 & 18 & 9 & - \\
\hline UQP-13/7 & $9 \mathrm{R}, \mathrm{CC}$ & 477 & 5 & 185 & 468 & 148 & 115 & 5 & 5 & - \\
\hline UQP-38/1 & $10 \mathrm{R}-1,9-14$ & - & - & - & 10 & - & 48 & 58 & - & - \\
\hline UQP-38/2 & 10R-2, 9-14 & 63 & - & 8 & 16 & - & 8 & 8 & - & - \\
\hline UQP-38/3 & $10 \mathrm{R}-3,9-14$ & 1,266 & 18 & $1,081^{\circ}$ & 5,704 & 2,676 & 74 & 74 & 46 & - \\
\hline UQP-38/4 & $10 \mathrm{R}-4,9-14$ & 88 & - & - & 2,099 & 569 & 119 & 18 & - & - \\
\hline UQP-13/8 & $10 \mathrm{R}, \mathrm{CC}$ & 193 & 51 & - & 1,135 & 168 & 503 & 26 & 52 & - \\
\hline UQP-38/5 & $11 R-1,29-34$ & 392 & 69 & 161 & 1,682 & 970 & 161 & 92 & - & - \\
\hline UQP-38/6 & $11 \mathrm{R}-2,29-34$ & 134 & - & 50 & 201 & 75 & 310 & 8 & 8 & - \\
\hline UQP-39/1 & $11 \mathrm{R}-3,29-34$ & 264 & 226 & 13 & 1,799 & 818 & 703 & 52 & 39 & - \\
\hline UQP-39/2 & $11 R-4,29-34$ & 77 & - & - & 15 & - & 46 & 8 & - & - \\
\hline UQP-14/1 & $11 \mathrm{R}, \mathrm{CC}$ & 560 & 8 & 488 & 1,404 & 542 & 249 & 9 & 18 & - \\
\hline UQP-39/3 & $12 \mathrm{R}-1,33-38$ & 29 & - & - & 19 & - & - & 9 & - & - \\
\hline UQP-39/4 & $12 \mathrm{R}-2,33-38$ & 530 & 82 & 40 & 1,896 & 550 & 408 & 20 & - & - \\
\hline UQP-39/5 & $12 \mathrm{R}-3,33-38$ & 960 & 80 & 672 & 2,306 & 1,856 & 128 & 64 & 16 & - \\
\hline UQP-39/6 & $12 \mathrm{R}-4,33-39$ & 843 & 76 & 383 & 1,499 & 342 & 652 & 38 & 38 & - \\
\hline UQP-14/2 & $12 \mathrm{R}, \mathrm{CC}$ & 7 & - & - & 7 & - & 7 & - & - & - \\
\hline UQP-14/3 & $13 \mathrm{R}, \mathrm{CC}$ & - & - & - & 8 & 8 & - & - & - & - \\
\hline
\end{tabular}

cene sediments of Site 646. The abundance of the acritarchs $C y$ matiosphaera sp. I and Incertae sedis I also seems characteristic of high-latitude Pliocene sediments in the North Atlantic, including Baffin Bay (de Vernal and Mudie, this volume), Norwegian Sea (Mudie, 1988) and Gardar Drift south of Iceland (Mudie, 1986), in addition to the Labrador Sea.

\section{CONCLUSIONS}

The dinocyst and acritarch stratigraphy of Labrador Sea Sites 646 and 647 suggests that major changes occurred in surface-water conditions during the Pliocene-Pleistocene, especially off southwest Greenland. During the Pliocene, the eastern Labrador Sea was probably characterized by high primary productivity that may have been related to nutrient influx from the shelf or to upwelling, as suggested by abundant acritarchs, Peridiniaceae cysts, and Tasmanidae. The decreasing dinocyst and acritarch concentrations throughout the Pliocene-early Pleistocene interval suggest a reduction in primary productivity. This interval also corresponds to a significant decrease in dinocyst diversity that probably reflects a change from cool-temperate to more rigorous subarctic environmental conditions. The dinocyst assemblages are generally boreal in character throughout the Pliocene-Pleistocene interval, but the frequent occurrence of warm-temperate to tropical species, such as Impagidinium aculeatum and Impagidinium patulum, suggests that a small but significant volume of North Atlantic Drift water continued to flow northward into the Labrador Sea.

The pollen and spore assemblages show variations in influx that are probably related to changes in the vegetation of southeastern Canada. A cool-temperate forest with Tsuga and Sciadopitys and some areas of temperate Quercus woodland were apparently replaced by widespread coniferous boreal forest vegetation during the late Pliocene. 


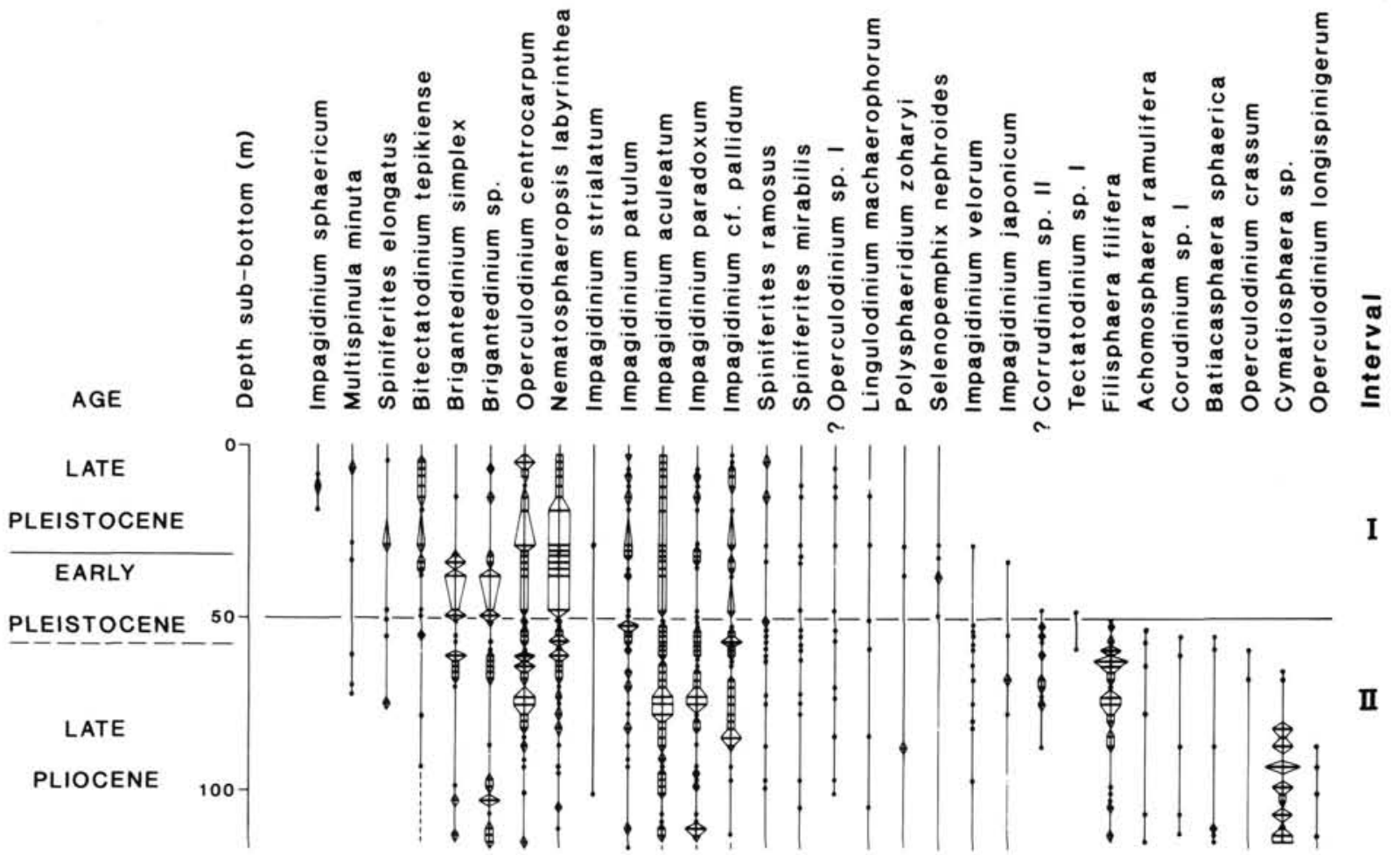

Figure 6. Stratigraphic range of dinoflagellate cysts and acritarchs in Pliocene-Pleistocene sediments of Site 647.

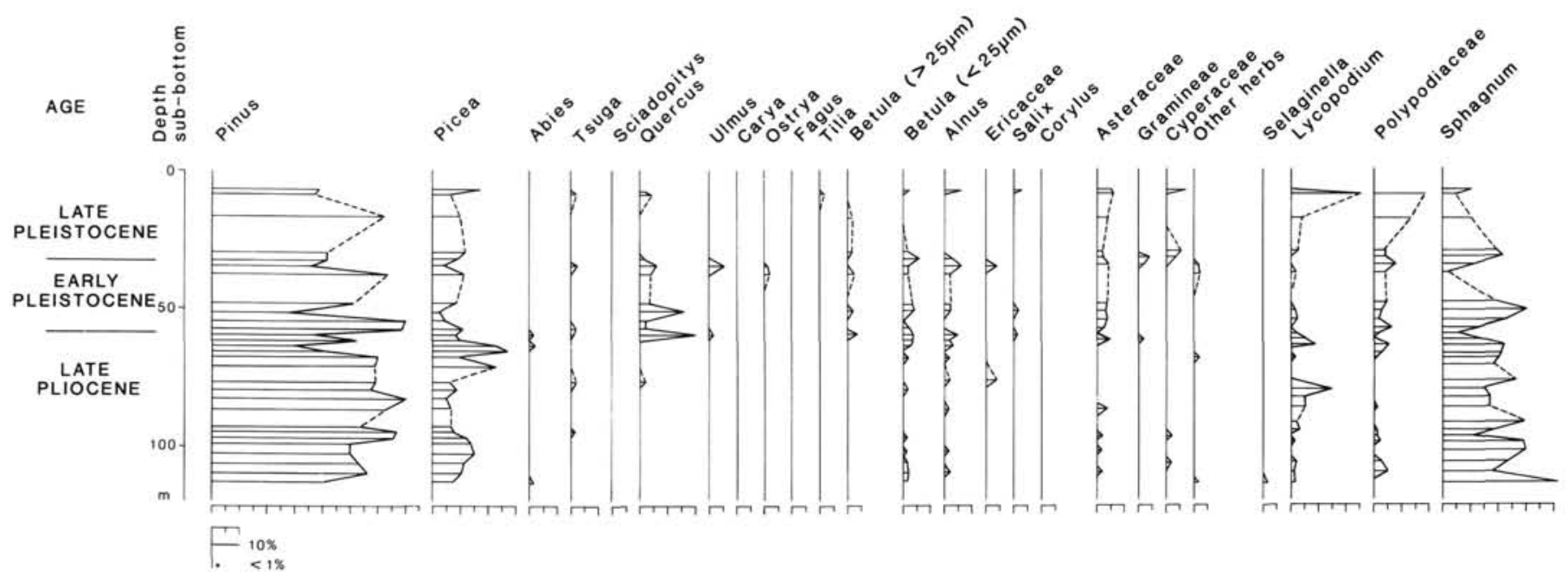

Figure 7. Summarized diagram of pollen and spore percentages at Site 646 (see remarks for Fig. 4).

\section{SYSTEMATIC DESCRIPTIONS}

Division PYRRHOPHYTA Pascher 1914

Class DINOPHYCEAE Fritsch 1929

Order PERIDINIALES Haeckel 1894

Genus ACHOMOSPHAERA Evitt 1963

Achomosphaera andalousiensis Jan du Chêne, 1977

(Pl. 2, Figs. 13-15)

Remarks. The observed specimens show slightly more rigid, larger processes than the holotype. At Site 646, A. andalousiensis is recorded in Pleistocene interglacial sediments of isotopic stage 7 (Aksu et al., this volume). The relatively high concentrations of $A$. andalousiensis ( $>100$ / $\left.\mathrm{cm}^{3}\right)$ in some middle Pleistocene samples suggest local production rather than reworking. The stratigraphic range of Achomosphaera andalousiensis may extend to the Pleistocene in the northeast Labrador Sea.
Achomosphaera ramulifera (Deflandre) Evitt, 1963

(Pl. 2, Figs. 5 and 6)

Genus ATAXIODINIUM Reid 1974
Ataxiodinium choanum Reid, 1974

(Pl. 5, Fig. 17)

Occurrence. This species is found scattered in upper Pleistocene sediments from Site 646 (Aksu et al., this volume).

\section{Genus BATIACASPHAERA Drugg 1970 \\ Batiacasphaera sphaerica Stover, 1977}

(Pl. 3, Figs. 17-19)

Description. Cysts of Batiacasphaera sphaerica observed in sediments from Site 646 are spherical to subspherical and relatively small. Diameter varies from 24 to $36 \mu \mathrm{m}$ and averages $30 \mu \mathrm{m}(\mathrm{N}=11)$. The 


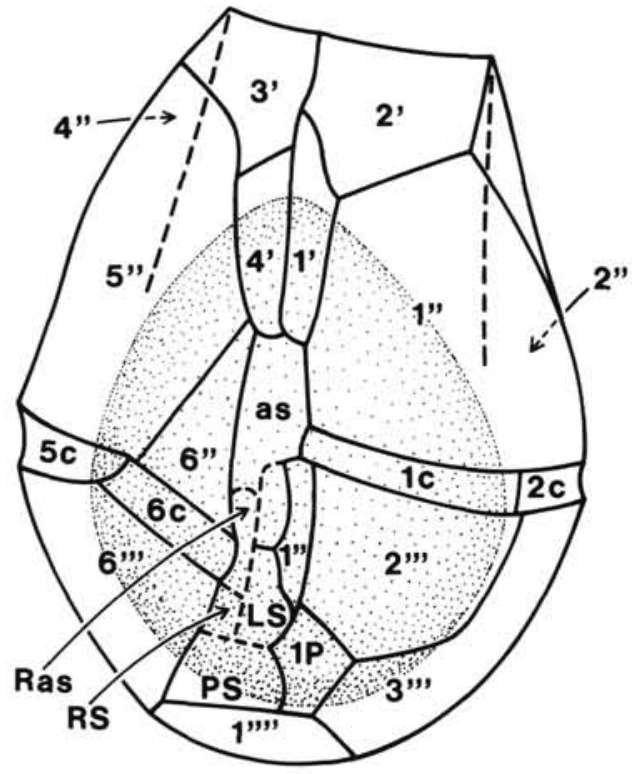

Figure 8. Paratabulation of Invertocysta sp. I. Plates are labeled with the conventional Kofoid designations.

autophragm is thin and covered by small granules joined to form a coarse microreticulation. The apical archeopyle, generally free, corresponds to the displacement of paraplates $1^{\prime}$ to $3^{\prime}$. The operculum may be in-situ (see Pl. 3, Fig. 18).

Occurrence. Batiacasphaera sphaerica is abundant in lower Pliocene sediment from the Labrador Sea (Site 646) and can be scattered in upper Pliocene sediments from Labrador Sea Sites 646 and 647.

Genus BITECTATODINIUM Wilson 1973

Bitectatodinium tepikiense Wilson, 1973

(Pl. 4, Figs 9-11)

Remarks. The archeopyle formed by the loss of two precingular paraplates ( $2^{\prime}$ and $\left.3^{\prime \prime}\right)$ is usually open (Pl. 4, Fig. 10) although one or both plates can be in-situ (Pl. 4, Figs. 11 and 9).

Occurrence. In the Labrador Sea, B. tepikiense is found mainly in Pleistocene deposits. It is frequently present but rarely abundant, with the exception of some interglacial episodes (Aksu et al., this volume; de Vernal and Hillaire-Marcel, 1987a).

Genus BRIGANTEDINIUM Reid 1977

Brigantedinium simplex (Wall, 1965) Reid, 1977

(Pl. 5, Fig. 11)

Brigantedinium $\mathrm{sp}$.

Remarks. The archeopyle sutures cannot be distinguished on many cysts of Brigantedinium because of poor preservation, orientation, or folding; it is often difficult to speciate the genus. Brigantedinium sp. includes all round, brown, protoperidinioid cysts except $B$. simplex.

\section{Genus CORRUDINIUM Stover and Evitt, 1978 \\ Corrudinium harlandii Matsuoka, 1983 \\ Corrudinium sp. I \\ (Pl. 3, Figs. 14-16)}

Description. These dinocysts are similar to $C$. incompositum (Drugg, 1970) Stover and Evitt, 1978, from which they differ by being distinctly ovoidal, with the hypocyst bigger and rounder than the epicyst. In addition, the parasutural and accessory septa appear equally well developed, thick, straight or slightly curved, and of uniform height. The area between the septa is smooth or scabrate, without any granular ornamentation. The archeopyle is precingular and reduced. The polar and equatorial axes of Corrudinium sp. I are 30 and $26 \mu \mathrm{m}$ long, respectively $(\mathrm{N}=$ 5). The height of the parasutural and accessory septa is $3 \mu \mathrm{m}$. The septa are almost $1 \mu \mathrm{m}$ thick.

Occurrence. Corrudinium sp. I is common in lower Pliocene sediments from the Labrador Sea (Site 646). It is scattered in upper Pliocene sediments from the Labrador Sea (Sites 646 and 647).
?Corrudinium sp. II

(Pl. 3, Figs. 11 and 12)

Description. The cysts are small ( 22 to $30 \mu \mathrm{m}$ long; $N=4$ ), subspherical, and are characterized by a dense network of undulating crests that make it impossible to distinguish the paratabulation. The archeopyle is precingular, and the operculum is free. The field areas between crests are smooth. The taxonomic affinity of these cysts with the genus Corrudinium is uncertain since the accessory crests cannot be distinguished from the parasutural ones: the only clearly delineated parasutural feature is the paracingulum.

Occurrence. ?Corrudinium sp. II is frequently observed in Pliocene and lower Pleistocene sediments of Labrador Sea Sites 646 and 647. It is never abundant.

\section{Genus FILISPHAERA Bujak 1984 \\ Filisphaera filifera Bujak, 1984}

(PI. 4, Figs. 1 and 2)

Remarks. Dinocysts from the Labrador Sea assigned to $F$. filifera vary considerably in size. The diameter ranges from about 35 to $55 \mu \mathrm{m}$. The thickness of the wall also varies between 2 and $4 \mu \mathrm{m}$. In a single sample, the size range is relatively uniform. The larger cysts of $F$. filifera are recorded in a few samples dated from the late Pliocene to the early Pleistocene. In these samples, $F$. filifera may be particularly abundant $\left(>1000\right.$ cysts $/ \mathrm{cm}^{3}$ ) and constitutes the dominant taxon. Many specimens of $F$. filifera have a well-developed apical boss (see Pl. 4, Fig. 1). The precingular archeopyle ( $\left.3^{\prime}\right)$ is generally open, although the operculum can be in-situ. The radiating fibers that compose the outer wall are usually straight, but can sometimes be slightly curved, which gives a microreticulate appearance to the outer cyst wall (see Pl. 4, Fig. 2). F. filifera specimens having slightly curved radiating fibers are difficult to distinguish from Bitectatodinium tepikiense, especially when the orientation or folding obscures the archeopyle.

Occurrence. In the Labrador Sea, $F$. filifera is common in Pliocene and lowest Pleistocene sediments.

Genus IMPAGIDINIUM Stover and Evitt 1978

Impagidinium aculeatum (Wall, 1967) Lentin and Williams, 1981 (Pl. 1, Figs. 5 and 6)

Remarks. Impagidinium aculeatum is recorded in small numbers through the Pliocene-Pleistocene in the Labrador Sea. Specimens are slightly larger in Pliocene and lower Pleistocene sediments than in modern ones. This size gradation also was observed in central North Atlantic at DSDP Sites 611 and 607 (Mudie, 1986).

$$
\begin{aligned}
& \text { Impagidinium japonicum Matsuoka, } 1983 \\
& \text { (Pl. 1, Figs. } 17 \text { and 18) } \\
& \text { Impagidinium cf. pallidum Bujak, } 1984 \\
& \text { (Pl. 1, Figs. } 15 \text { and 16) }
\end{aligned}
$$

Description. Specimens from Labrador Sea sediments are similar to I. pallidum Bujak, 1984, with respect to the thinness and transparency of the wall, the smoothness of the parasutural crests, and the frequent folding. The observation of several well-preserved specimens from Holocene Labrador Sea sediments suggests the following paratabulation: $3^{\prime}, 6^{\prime \prime}, 4 c, 4^{\prime \prime \prime}$ or $5^{\prime \prime \prime}$, and $1^{\prime \prime \prime} "$. The parasulcal region is clearly outlined by parasutural septa, but no sulcal paratabulation is evident. The archeopyle is reduced, precingular, and is formed by the loss of paraplate 3 ". The height of the parasutural septa varies: the longest sutures exhibit the widest septa. The length of the polar axis varies from 58 to $78 \mu \mathrm{m}$, and the crest height ranges from 3 to $7 \mu \mathrm{m}(\mathrm{N}=14)$.

Occurrence. In the Labrador Sea, Impagidinium cf. pallidum is common in Pliocene to Holocene sediments, while I. pallidum has a reported age range from Eocene to earliest Pleistocene in the North $\mathrm{Pa}$ cific and Bering Sea (Bujak, 1984).

Impagidinium paradoxum (Wall, 1967) Stover and Evitt, 1978 (Pl. 1, Figs. 3 and 4)

Impagidinium patulum (Wall, 1967) Stover and Evitt, 1978 (Pl. 1, Figs. 1 and 2)

Impagidinium sphaericum (Wall, 1967) Lentin and Williams, 1981 (Pl. 1, Figs. 7-9)

Occurrence. In the Labrador Sea, I. sphaericum occurs exclusively in upper Pleistocene sediments and is common in Holocene sediments (de Vernal, 1986). The modern distribution of $I$. sphaericum ranges 
from tropical (e.g., Harland, 1983) to subarctic climatic zones (de Vernal, 1986) and suggests a wide temperature tolerance.

$$
\begin{aligned}
& \text { Impagidinium velorum Bujak, } 1984 \\
& \text { (Pl. 1, Figs. } 19 \text { and 20) } \\
& \text { Impagidinium sp. I } \\
& \text { (Pl. 1, Figs. 10-12) }
\end{aligned}
$$

Remarks. Impagidinium cysts with unknown species affinity are recorded in several samples from Labrador Sea sediments. Because these cysts are usually rare and poorly preserved, we made no attempt to differentiate most of them. However, one of these forms (Pl. 1, Figs. 10 12), is common in a few lower Pliocene samples. This form is referred to here as Impagidinium sp. I. This morphotype is similar to Impagidinium sphaericum, from which it differs by a more oblate shape, absence of apical boss, and less distinct sulcal paratabulation.

\section{Genus IMPLETOSPHAERIDIUM Morgenroth 1966 Impletosphaeridium $\mathrm{sp} . \mathrm{I}$}

Remarks. Specimens of Impletosphaeridium sp., scattered in lower Pliocene sediments of Site 646, appear similar to Impletosphaeridium sp. I of Manum (1976). According to Matsuoka (1983), Impletosphaeridium sp. I Manum could belong to the species Reticulatosphaera stellata, which is characterized by intratabular processes with trifucate distal ends, apparently twiglike and connected by trabecula. Specimens of Impletosphaeridium sp. I observed in Pliocene sediments from the Labrador Sea and Baffin Bay, however, cannot be referred to Reticulatosphaera stellata Matsuoka, 1983, because of the lack of trabeculae joining processes.

\author{
Genus INVERTOCYSTA Edwards 1984 \\ Invertocysta lacrymosa Edwards, 1984 \\ (PL. 4, Figs. 16 and 17) \\ Invertocysta $\mathrm{sp}$. I \\ (Pl. 4, Figs. 12-15; text, Fig. 8)
}

Description. This cavate cyst is characterized by a ventrally adpressed periphragm and endophragm. The paratabulation, which is clearly outlined on the periphragm, especially in the ventral view (see Pl. 4, Figs. 12 and 13), is $4^{\prime}, 6^{\prime \prime}, 6 \mathrm{c}, 6^{\prime \prime \prime}, 1 \mathrm{p}, 1^{\prime \prime \prime}$, and $5 \mathrm{~s}$ (text, Fig. 8). The archeopyle is delineated on the periphragm by a large opening that corresponds to the paraplate $3^{\prime \prime}$. The endocyst is elongate and 48 to $58 \mu \mathrm{m}$ long; the maximum length of the periphragm is about 76 to $84 \mu \mathrm{m}$. Invertocysta sp. I differs from I. tabulata Edwards, 1984 in having more distinct ventral paratabulation and a larger endocyst without an apical protrusion.

Occurrence. Invertocysta sp. I is common in the uppermost lower Pliocene sediments from Site 646.

Genus LEJEUNECYSTA Artzner and Dorhofer 1978

Lejeunecysta cf. fallax (Morgenroth, 1966) Artzner and Dorhofer 1978

(Pl. 5, Fig. 12)

Remarks. The dinocysts attributed to Lejeunecysta cf. fallax show variations in the length of their equatorial ( 52 to $66 \mu \mathrm{m}$ ) and polar (56 to $78 \mu \mathrm{m})$ axes.

$$
\begin{gathered}
\text { Lejeunecysta paratenella (Benedek 1972) Artzner and Dorhofer } \\
1978 \\
\text { (Pl. 5, Fig. 13) }
\end{gathered}
$$

Genus LINGULODINIUM Wall 1967

Lingulodinium machaerophorum (Deflandre and Cookson, 1955)

Wall, 1967

(Pl. 3, Fig. 10)

Genus MULTISPINULA Bradford 1975

Multispinula minuta Harland and Reid in Harland et al., 1980 (Pl. 5, Fig. 6)

Multispinula quanta Bradford, 1975

(Pl. 5, Fig. 10)

Occurrence. $M$. quanta can be scattered in Pleistocene sediments from Site 646 (Aksu et al., this volume).
Genus NEMATOSPHAEROPSIS Deflandre and Cookson, 1955 Nematosphaeropsis labyrinthea (Ostenfeld, 1903) Reid, 1974

(Pl. 2, Figs. 12 and 16)

Remarks. N. labyrinthea, which occurs through the Pliocene-Pleistocene, shows variations in size from about 40 to $70 \mu \mathrm{m}$ in total diameter. Both robust and fragile forms are illustrated in Figures 16 and 12 of Plate 2. On the whole, small Nematosphaeropsis labyrinthea cysts are more frequent in Pleistocene sediments.

\section{Nematosphaeropsis sp. I}

(Pl. 2, Figs. 9-11)

Description. Cysts of Nematosphaeropsis sp. I are distinguished by their small size ( 25 to $30 \mu \mathrm{m}$ ) and by processes, which are joined by single trabeculae. The body diameter varies from 15 to $20 \mu \mathrm{m}$, while the process length is 4 to $6 \mu \mathrm{m}$. Nematosphaeropsis sp. I differs from Nematosphaeropsis aquaeducta Piasecki, 1980, which is larger and bears massive processes.

Occurrence. Nematosphaeropsis sp. I is recorded in a few upper Pliocene samples from Site 646

Genus OPERCULODINIUM Wall 1967

Operculodinium centrocarpum (Deflandre and Cookson, 1955) Wall, 1967

(Pl. 3, Figs. 1-4)

Remarks. In Pliocene-Pleistocene sediments from the Labrador Sea, cysts of $O$. centrocarpum show wide variation in body size and process length. A specimen bearing very short processes $(2 \mu \mathrm{m})$ is illustrated in Figures 3 and 4 of Plate 3 . Such a form was observed in both Pliocene and Pleistocene sediments.

Operculodinium crassum Harland, 1979

$$
\text { (P1. 3, Figs. 7-9) }
$$

Remarks. Operculodinium crassum varies widely in body size and in process length. It is common in a few lower Pliocene samples from Site 646 and is scattered in upper Pliocene deposits from the Labrador Sea Sites 646 and 647 .

Operculodinium longispinigerum Matsuoka, 1983

(Pl. 3, Figs. 5 and 6)

?Operculodinium $\mathrm{sp}$. 1

$$
\text { (Pl. 3, Fig. 13) }
$$

Description. Cysts are subspherical, have no processes, and are characterized by microgranular ornamentation. Microgranules form an irregular, nontabular reticulation. Archeopyle is precingular of type $\mathrm{P}$ and constitutes the only expression of the paratabulation.

Occurrence. Operculodinium sp. I has been recorded in Pliocene and Pleistocene sediments of the Labrador Sea.

Genus POLYSPHAERIDIUM Davey and Williams 1966 Polysphaeridium zoharyi (Rossignol, 1962) Bujak et al., 1980

Genus SELENOPEMPHIX Benedek 1972

Selenopemphix nephroides Benedek, 1972, emend, Bujak et al., 1980

(Pl. 5, Fig. 8)

Selenopemphix cf. armata Bujak et al., 1980

(Pl. 5, Fig. 9)

Remarks. We included in this category the Selenopemphix cysts bearing spines, although these spines may have a variable morphology.

\section{Genus SPINIFERITES Mantell 1850 Spiniferites elongatus Reid, 1974}

$$
\text { (Pl. 2, Figs. 2-4) }
$$

Here, this taxon includes both Spiniferites elongatus Reid, 1974, Spiniferites frigidus (Harland and Reid in Harland et al., 1980), and intergrades between these two taxa.

\section{Spiniferites mirabilis (Rossignol, 1962) Sarjeant, 1970}

$$
\text { (Pl. 2, Fig. 1) }
$$

Spiniferites ramosus (Ehrenberg, 1838) Loeblich and Loeblich, 1966

(PI. 2, Figs. 7 and 8) 
Genus TECTATODINIUM Wall 1967

Tectatodinium pellitum Wall 1967

Tectatodinium sp. I

(Pl. 4, Figs. 3-5)

Description. Tectatodinium sp. I is a spherical cyst characterized by a thick wall $(2.5-3 \mu \mathrm{m})$. The thin periphragm is supported by baculae that form a punctuated surface. Diameter varies from 36 to $45 \mu \mathrm{m}(\mathrm{N}=$ 4). Tectatodinium sp. I could be a morphotype of Tectatodinium pellitum.

\section{Tectatodinium sp. II \\ (Pl. 4, Figs. 6-8)}

Description. Cysts of Tectatodinium sp. II are distinguished by the ornamentation of the outer wall, which forms a clear, regular microreticulation. The operculum of the type $\mathrm{P}$ archeopyle may be in-situ. Cyst diameter varies from 36 to $51 \mu \mathrm{m}$ and averages $44 \mu \mathrm{m}(\mathrm{N}=40)$; the wall is $2-2.3 \mu \mathrm{m}$ thick. Tectatodinium sp. II may be a morphotype of Tectatodinium pellitum.

Occurrence. Tectatodinium sp. II is common in a few upper Pliocene samples from Hole 646B.

\section{Genus XANDARODINIUM Reid 1977 \\ Xandarodinium variabile Bujak, 1984}

(Pl. 5, Fig. 7)

Genus Uncertain

Cyst type I

(Pl. 5, Figs. 1-5)

Description. Cyst type I is small, chorate, and subspherical to ellipsoidal. Body bears massive processes with trifurcate or tetrafurcate terminations joined by thick trabeculae. Processes are numerous and uniformly distributed around the body. Consequently, trabeculae are short and give an alveolar appearance to the outer cyst. The latter is characterized by a polygonal opening that corresponds to the archeopyle (Pl. 5 , Fig. 1), which appears precingular. The relationship between process distribution and paratabulation is unclear. However, the dense and relatively uniform pattern of processes and their positions around the archeopyle does suggest intratabular distribution. Diameter of the central body varies from 12 to $17 \mu \mathrm{m}$; the polar axis length of the overall cyst ranges from 21 to $35 \mu \mathrm{m}$ and averages $27 \mu \mathrm{m}(\mathrm{N}=50)$.

Occurrence. Cyst type I is abundant in lower Pliocene sediments of the Labrador Sea (Site 646). Because it occurs in large numbers and has a narrow stratigraphic range, Cyst type I may be a good stratigraphic marker for the Labrador Sea region.

\section{Division CHLOROPHYTA Pascher 1914}

Class CHLOROPHYCEAE Kutzing 1843

Order CHLOROCOCCALES Pascher 1915

Family HYDRODICTYACEAE Dumortier 1829 Genus PEDIASTRUM Meyen 1829

Remarks. Colonies of the algae Pediastrum were scattered in Pliocene-Pleistocene sediments of Labrador Sea Sites 646 and 647. Most belong to the species Pediastrum boryanum (Turpin) Meneghini, 1840, which is an ubiquitous freshwater form (e.g., Prescott, 1953; Prescott and Vinyard, 1965). In deep-sea sediments, the occurrence of Pediastrum boryanum probably is related to runoff from the continent.

Division PRASINOPHYTA Round 1971

Order PTEROSPHERMALES Schiller 1925

Family TASMANIDACEAE Sommer 1956

Undifferentiated tasmanides frequently were observed in Pliocene sediments from Labrador Sea Site 646 (See Table 1).

\section{INCERTAE SEDIS \\ Group ACRITARCHA Evitt 1963 \\ Subgroup PTEROSPERMOPSIS Downie 1973 \\ Genus CYMATIOSPHAERA (Wetzel) Deflandre 1954 \\ Cymatiosphaera sp. I \\ (Pl. 5; Figs. 14-16)}

Remarks. In the Pliocene sediments of the Labrador Sea, Cymatiosphaera sp. I is abundant and often dominates the marine palynomorph assemblages. Large variations in the size of the overall cysts (12 to 30 $\mu \mathrm{m})$ and of the height of intersecting crests ( 2 to $7 \mu \mathrm{m})$ were observed. Several species or morphotypes therefore may be represented by the genus Cymatiosphaera.

According to phycologists, the fossil Cymatiosphaera represents the cyst stage or phycoma of green algae (Boalch and Parke, 1971) that belong to Division Prasinophyta Round 1971, Order Sperospermatales Schillers 1925, and Family Cymatiosphaeraceae Madler 1963.

\section{Incertae sedis I}

(Pl. 5, Figs. 20 and 23)

Description. This taxon designates small cysts (12 to $25 \mu \mathrm{m}$ ) having a Pterospermopsis-type of wall, i.e., having a surface divided into fields by a reticulum of intersecting crests (Downie, 1973). Incertae sedis I is characterized by large fields and wide (up to $6 \mu \mathrm{m}$ ), thick, massive crests. Crests are more or less striate; in optical section, their margins are straight to ondulating or even spiny. The intersections between crests are nodal. A pylome with a subrectangular outline may be observed. According to its morphology, Incertae sedis I could be included in the Cymatiosphaera genus. As Cymatiosphaera, it probably represents the cyst stage of a Prasinophyta.

Occurrence. Incertae sedis I is abundant in upper Pliocene sediments of the Labrador Sea.

\section{Incertae sedis II}

$$
\text { (Pl. 5; Figs. } 18 \text { and 19) }
$$

Description. This taxon is probably a Pterospermopsis-type of acritarch. It is small ( 15 to $25 \mu \mathrm{m}$ ) and characterized by a dense network of massive cones and/or spines that are apparently connected along crests. A pylome with a subrectangular outline frequently was observed.

Occurrence. Incertae sedis II was observed in small numbers throughout the Pliocene sediments from Site 646.

\section{Palynoplankton INCERTAE SEDIS Genus HALODINIUM Bujak 1984}

Description. Specimens of Halodinium observed in sediments from Site 646 are relatively large (about 50 to $75 \mu \mathrm{m}$ in total diameter). They have a discoidal, thin, brownish endophragm with a semitransparent, smooth, irregular periphragm. Central pylome (15 to $20 \mu \mathrm{m}$ in diameter) is always free. The taxonomic affinity of Halodinium is unknown.

Occurrence. Halodinium microfossils were scattered in Pliocene and Pleistocene sediments from Site 646.

\section{ACKNOWLEDGMENTS}

Technical support was provided by C. Goyette and C. Lavergne for laboratory processing and by $\mathrm{M}$. Laithier for drafting. EMR-Canada support to ODP, financial assistance from NSERC-Canada (Grants A9156 and CSP-Leg 105), FCAR Funds of Québec (Grant EQ-492), and support of the Geological Survey of Canada (Project 82-0044) were essential. We sincerely thank G. Norris, G. L. Williams, and S. P. Srivastava for their critical and constructive reviews of the manuscript.

\section{REFERENCES}

Aksu, A. E., and Mudie, P. J., 1985. Magnetostratigraphy and palynology demonstrate at least 4 million years of Arctic Ocean sedimentation. Nature, 318:280-283.

Al-Ameri, T. K., 1986. Observations on the wall structure and excystment mechanism of acritarchs. J. Micropaleontol., 5:27-38.

Artzner, D. G., and Dorhofer, G., 1978. Taxonomic note: Lejeunecysta nom, nov. pro. Lejeunia Gerlach 1961 emend. Lentin and Williams 1976 - dinoflagellate cyst genus. Can. J. Botany, 56:1381-1382.

Backman, J., 1979. Pliocene Biostratigraphy of DSDP Sites 111 and 116 from the North Atlantic Ocean and the age of Northern Hemisphere glaciation. Stockolm Contrib. Geol., 32:115-137.

Benedek, P. N., 1972. Phytoplanktonen aus dem Mittel- und Oberoligozan von Tönisberg (Niederrheingebiet). Paleontographica (Abt. B), 137:1-71.

Berggren, W. A., Kent, D. V., Flynn, J. J., and Van Couvering, J. A. 1985. Cenozoic geochronology. Geol. Soc. Am. Bull., 96:1407-1418.

Boalche, G. T., and Parke, M., 1971. The Prasinophycean genera (Chlorophyta) possibly related to fossil genera, in particular the genus Tasmanides. Proc. 2nd Plankton Conf., Roma, 1970, 1:99-105.

Bradford, M. R., 1975. New dinoflagellate cyst genera from the Recent sediments of the Persian Gulf. Can. J. Botany, 53:3064-3074. 
Bujak, J. P., 1984. Cenozoic dinoflagellate cysts and acritarchs from the Bering Sea and northern North Pacific, DSDP Leg 19. Micropaleontology, 30:180-212.

Bujak, J. P., Downie, C., Eaton, G. L., and Williams, G. L., 1980. Dinoflagellate cysts and acritarchs from the Eocene of southern England. Palaeontol. Assoc. Spec. Pap., 24:1-100.

Dale, B. 1976. Cyst formation, sedimentation and preservation: factors affecting dinoflagellate assemblages in Recent sediments from Trondheimsfjord, Norway. Rev. Paleobot. Palyn., 22:39-60.

1983. Dinoflagellate resting cysts: "benthic plankton." In Fryxell, G. A. (Ed.), Survival Strategy of the Algae: Cambridge (Cambridge Univ. Press), 69-136.

Davey, R. J., and Williams, G. L., 1966. The genera Hystrychosphaera and Achomosphaera. In Davey, R. J., Downie, C., Sarjeant, W.A.S., and Williams, G. L., Studies on Mesozoic and Cainozoic Dinoflagellate cysts: London (Bull. British Mus. Geol.), 3:28-52.

Deflandre, G., 1954. Systématique des Hystrichospaeridés: sur l'acceptation du genre Cymatiosphaera O. Wetzel. Comptes Rend. Soc. Géol. France, 12:257-258.

Deflandre, G., and Cookson, I. C., 1955. Fossil microplankton from Australian late Mesozoic and Tertiary sediments. Austral. J. Mar. Freshwater Res., 6:242-313.

de Vernal, A., 1986. Analyses palynologiques et isotopiques de sédiments de la mer du Labrador et de la baie de Baffin: éléments d'une climatostratigraphie du Quaternaire supérieur dans l'est du Canada (Ph.D. dissert.). Université de Montréal, Montréal.

de Vernal, A., and Hillaire-Marcel, C., 1986. Paléoenvironnements du Wisconsinien moyen dans l'est du Canada par l'analyse palynologique et isotopique de sequences sédimentaires continentales et océaniques: quelques aspects. Rev. Géol. Dyn. Géogr. Phys., 27:119-130. ,1987a. Paleoenvironments along the eastern Laurentide ice sheet margin and timing of the last ice maximum and retreat. Géogr. Phys. Quat., 51:265-267.

1987b. Eléments d'une climatostratigraphie du Pléistocène moyen et supérieur dans l'est du Canada par l'analyse palynologique et isotopique du forage 84-030-003, mer du Labrador. Can. J. Earth Sci., 24:1886-1502.

de Vernal, A., Richard, P., and Jetté, H., 1983. Sur les effects de la technique de Lüber utilisée en analyse pollinique pour éliminer la matière organique non-décomposée. Pollen et Spores, 25:541-548.

de Vernal, A., Larouche, A. and Richard, P.J.H., 1987. Evaluation of the palynomorph concentrations: do the aliquot and the markergrains methods yield comparable results ? Pollen et Spores, 29:291304.

Downie, C., 1973. Observation on the nature of the acritarchs. Paleontology, 16:239-259.

Drugg, W. S., 1970. Some new genera, species, and combinations of phytoplankton from the lower Tertiary of the Gulf Coast, U.S.A. North Am. Paleontol. Conv., G:809-843.

Edwards, L. E., 1984. Miocene dinocysts from Deep Sea Drilling Project Leg 81, Rockall Plateau, eastern North Atlantic Ocean. In Roberts, D. G., Schnitker, D., et al., Init. Repts. DSDP, 81: Washington (U.S. Govt. Printing Office), 581-594.

Eldholm, O., Thiede, J., et al., 1987. Proc. ODP, Init. Repts, 104: College Station, TX (Ocean Drilling Program).

Erhenberg, C. G., 1838. Über das Massenverhaltniss der jetzt lebenden Kiesel-Infusorien and über ein neues Infusorien-Conglomerat als Polirschiefer von Jastrada in Ungarn. Abh. Preuss. Akad. Wiss., 1839:109-135.

Evitt, W. R., 1963. A discussion and proposals concerning fossile dinoflagellates, hystrichospheres, and acritarchs. Proc. Nat. Acad. Sci., 49:158-164.

Harland, R., 1979. Dinoflagellate biostratigraphy of Neogene and Quaternary sediments at Holes 400/400A in the Bay of Biscay (Deep Sea Drilling Project Leg 48). In Montadert, L., Roberts, D. G., et al., Init. Repts. DSDP, 48: Washington (U.S. Govt. Printing Office), 531-545.

1983. Distribution maps of recent dinoflagellate cysts in bottom sediments from the North Atlantic Ocean and adjacent seas. Paleontology, 26:321-387.

1984. Quaternary dinoflagellate cysts from Holes 548 and 549A, Goban Spur (Deep Sea Drilling Project Leg 80. In de Graciansky, P. C., Poag, C. W., et al., Init. Repts. DSDP, 80: Washington (U.S. Govt. Printing Office), 761-766.
Harland, R., Reid, P. C., Dobell, P., and Norris, G., 1980. Recent and subrecent dinoflagellate cysts from the Beaufort Sea, Canadian Arctic. Grana, 19:211-225.

Heusser, L. E., 1983. Pollen distribution in the bottom sediments of the western North Atlantic Ocean. Mar. Micropalentol., 8:77-88.

Holmes, R. W., 1956. The annual cycle of phytoplankton in the Labrador Sea, 1950-51. Bull, Bingham Oceanograph. Coll., 16:3-74.

Jan du Chêne, R., 1977. Étude palynologique du Miocène supérieur andalou (Espagne). Rev. Espan. Micropalentol, 9:97-114.

Lentin, J. K., and Williams, G. L., 1981. Fossil Dinoflagellates: Index to Genera and Species: Dartmouth (Bedford Inst. Oceanography), Rept. Ser. BI-R-81-12.

1985. Fossil Dinoflagellates: Index to Genera and Species. Ottawa (Fisheries and Oceans Canada), Can. Tech. Rept. Hydrogr. Ocean Sci., 60.

Loeblich, A. R., Jr., and Loeblich, A. R., III, 1966. Index to Genera, Subgenera, and Sections of the Pyrrhophyta: Miami (Studies in Tropical Oceanography).

Mantell, G. A., 1850. A Pictorial Atlas of Fossil Remains Consisting of Colored Illustrations Selected from Parkingson's "Organic Remains of a Former World," and Artis's "Antediluvian Phytology": London (H. G. Bohn).

Manum, S. B., 1976. Dinocysts in Tertiary Norwegian-Greenland Sea sediments (Deep Sea Drilling Project Leg 38). In Talwani, M., Udintsev, G., et al., Init. Repts. DSDP, 38: Washington (U.S. Govt. Printing Office), 897-919.

Margalef, R., 1978. Phytoplankton communities in upwelling areas, the example of NW Africa. Oecologica Aquatica, 3:97-132.

Matsuoka, K., 1983. Late Cenozoic dinoflagellates and acritarchs in the Niigata district, Central Japan. Palaeontographica, 187:89-154. 1985. Organic-walled dinoflagellate cysts from surface sediments of Nagasaki Bay and Sensaki Bay, West Japan. Bull. Fac. Lib. Arts, Nagasaki Univ., Nat. Sci., 25:21-115.

Matthews, J., 1969. The assessment of a method for the determination of absolute pollen frequencies. New Phytol., 68:161-166.

Meneghini, J., 1840. Desmidiearum Hucusque Cognitarum. Linnea, 14: 201-240.

Morgenroth, P., 1966. Mikrofossilien und Konkretionen des nordwesteuropaischen Untereozans. Palaeontographica, 119:1-53.

Mudie, P. J., 1980. Palynology of the later Quaternary marine sediments, eastern Canada [Ph.D. dissert.]. Dalhousie University, Hälifax.

1982. Pollen distribution in recent marine sediments, eastern Canada. Can. J. Earth Sci., 4:709-724.

1985. Palynology of the CESAR cores, Alpha Ridge. Geol. Surv. Can., Pap. 84-22:149-174.

1986. Palynology and dinoflagellate biostratigraphy of Deep Sea Drilling Project Leg 94, Sites 607 and 611, North Atlantic Ocean. In Ruddiman, W. F., Kidd, R. B., Thomas, E., et al., Init. Repts. DSDP, 94:Washington (U.S. Govt. Printing Office), 785-812.

1989. Palynology and dinocyst biostratigraphy of the late Miocene to Pleistocene, Norwegian Sea, ODP Leg 104, Sites 642 to 644. Proc. ODP, Sci. Results, 104: College Station, TX (Ocean Drilling Program).

Mudie, P. J., and Matthiessen, J., 1988. Palynology of surface sediments and cores. In Thiede, J., and Shipboard Scientists, Init. Results of RV Polarstern Cruise ARKTIS IV/3. Rept. on Polar Res., 43:144-185.

Mudie, P. J. and Short, S. K., 1985. Marine palynology of Baffin Bay. In Andrews, J. T. (Ed.), Quaternary Environments, Eastern Canadian Arctic, Baffin Bay and Western Greenland: London (Allan \& Unwin), 263-307.

Ostenfeld, C. H., 1903. Phytoplankton from the sea around Faeröes. Botany of the Faeröes, II: Copenhagen (Det Nordiske Forlag), 558612.

Piasecki, S., 1980. Dinoflagellate cyst stratigraphy of the Miocene Hodde and Gram formations. Denmark Geol. Surv. Den. Bull., 32:145-161.

Prescott, G. W., 1953. Preliminary notes on the ecology of freshwater algae in the Arctic slope, Alaska, with description of some new species. Am. Midland Nat., 50:464-473.

Prescott, G. W., and Vinyard, W. C., 1965. Ecology of Alaskan freshwater algae V: Limnology and flora of Malipuk Lake. Trans. Am. Microscop. Soc., 84:427-478.

Reid, P. C., 1974. Gonyaulacacean dinoflagellate cysts from the British Isles. Nova Hedwigia, 25:579-637. 
1977. Peridianiacean and Glenodiniacean dinoflagellate cysts from the British Isles. Nova Hedwigia, 29:429-463.

Richard, P., 1970. Atlas pollinique des arbres et de quelques arbustes indigénes du Québec. Nat. Can., 97:1-34, 97-161, 241-306.

Rossignol, M., 1962. Analyse pollinique de sédiments marins Quaternaires en Israël, II: Sédiments pléistocènes. Pollen et Spores, 4:121148.

Sarjeant, W.A.S., 1970. The genus Spiniferites Mantell, 1950 (Dinophyceae). Grana, 10:74-78.

Shackleton, N. J., Backman, J., Zimmerman, H., Kent, D. V., Hall, M. A., et al., 1984. Oxygen isotope calibration of the onset of icerafting and history of glaciation in the North Atlantic region. $\mathrm{Na}$ ture, 307:620-623.

Srivastava, S. P., Arthur, M. A., et al., 1987. Proc. ODP, Inits. Repts., 105: College Station, TX (Ocean Drilling Program).

Stein, J. A., and Duffield, S. L., 1985. Dinoflagellate cyst assemblages related to the Neogene history of the Beneguela upwelling system at Deep Sea Drilling Project Site 362 (Leg 40), Walvis Ridge, Southeastern Atlantic Ocean. Am. Assoc. Strat. Palynol., 18th Ann. Meet. 24. (Abstract)

Stover, L. E., 1977. Oligocene and early Miocene dinoflagellates from Atlantic Corehole 5/5B, Blake Plateau. Am. Assoc. Stragr. Palynol., Cont. Ser. 5A:66-89.

Stover, L. E., and Evitt, W. R., 1978. Analyses of Pre-Pleistocene Organic-Walled Dinoflagellates: Stanford (Stanford Univ. Press.), Geol. Sci., 15.

Takahashi, K. 1971. Microfossils from the Pleistocene sediments of the Ariake Sea area, west Kyushu. Pal. Soc. Japan, 81:11-26.

Tappan, H., 1980. The Paleobiology of Plant Protists: San Francisco (W. H. Freeman and Co.).

Turon, J. L., 1984. Le palynoplancton dans l'environnement actuel de l'Atlantique nord oriental. Evolution climatique et hydrologique de- puis le dernier maximum glaciaire. Mém. Inst. Geol. Bassin d'Aquitaine.

Usinger, H., 1975. Pollenanalytische und stratigraphische untersuchungen an zwei Spatglazial-vorkommen in Schleswig-Holstein: Hamburg (Mitteilungen der arbeitsgemeinschaft Geobotanik in Schleswig-Holstein und Hamburg), 25.

Wall, D. 1965. Modern hystrichospheres and dinoflagellate cysts from the Woods Hole region. Grana Palynol., 6:297-314.

1967. Fossil microplankton in deep-sea cores from the Caribbean Sea. Paleontology, 10:95-123.

1971. The lateral and vertical distribution of dinoflagellates in Quaternary sediments. In Funnel, B. M., and Riedel, W. R., The Micropaleontology of Oceans: London (Cambridge Univ. Press), 399405.

Wall, D., and Dale, B., 1968. Modern dinoflagellate cysts and the evolution of the Peridiniales. Mar. Micropaleontal., 14:265-304.

Wall, D., Dale, B., and Harrada, K., 1973. Descriptions of new fossil dinoflagellates from the Quaternary of the Black Sea. Micropaleontology, 19:18-31.

Wall, D., Dale, B., Lohmann, G. P., and Smith, W. K., 1977. Environmental and climatic distribution of dinoflagellate cysts in modern marine sediments from regions in the north and south Atlantic Ocean and adjacent seas. Mar. Micropaleontal., 2:121-200.

Wilson, G. J., 1973. Palynology of the middle Pleistocene Te Piki bed, Cape Runaway, New Zealand. New Zealand J. Geol. Geophys., 16: 345-354.

Date of initial receipt: 3 June 1987

Date of acceptance: 16 March 1988

Ms B105-134 


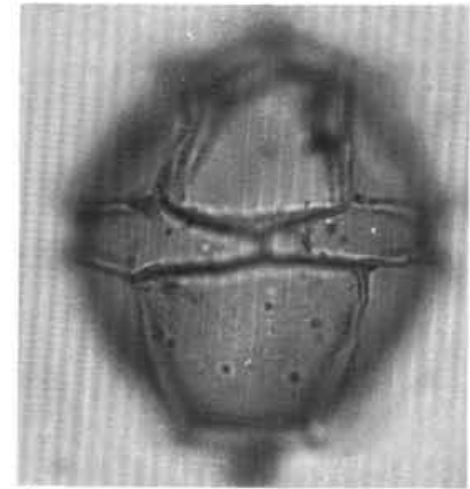

1

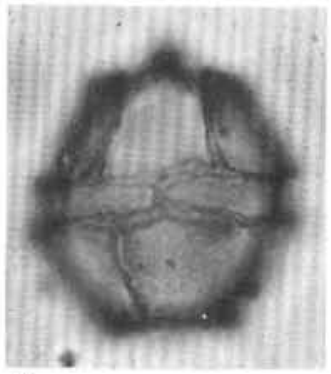

7

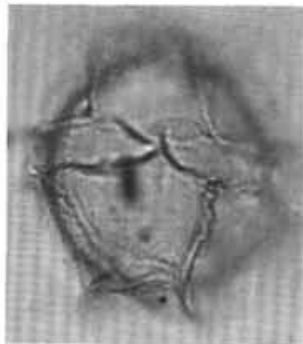

10

8

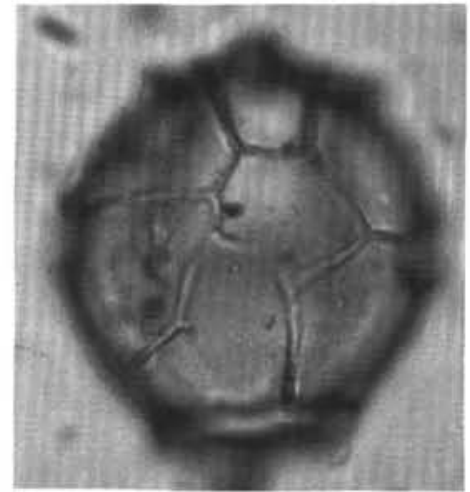

2
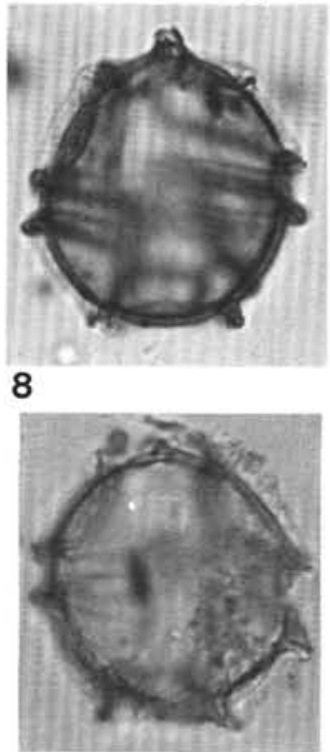

11

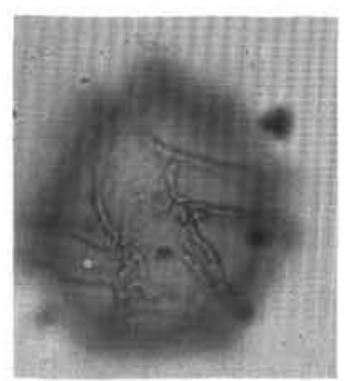

9

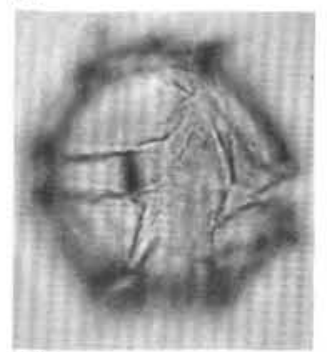

12

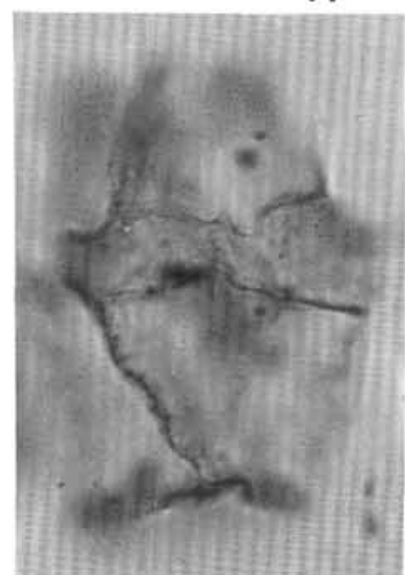

15

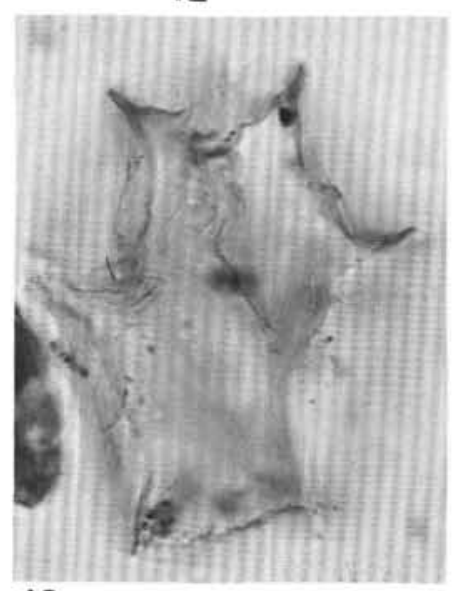

16

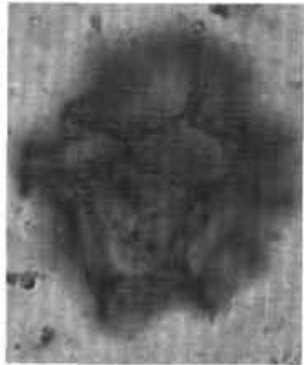

3

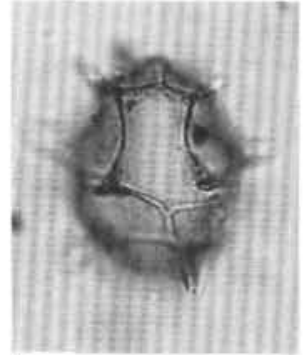

5

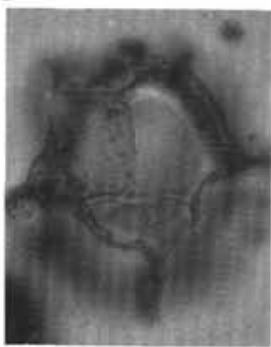

13

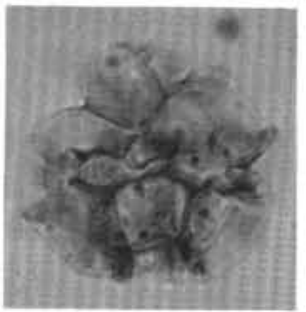

17

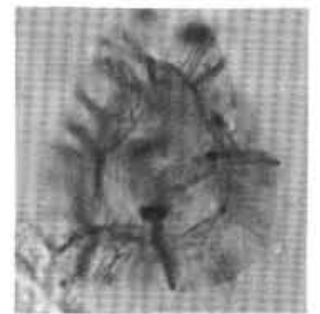

19

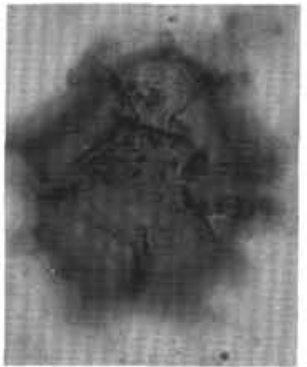

4

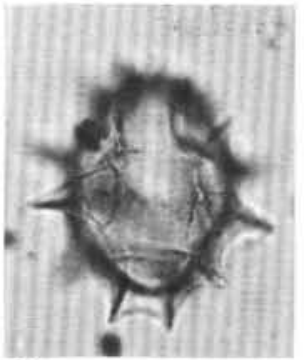

6

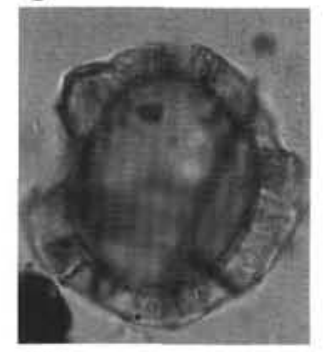

14

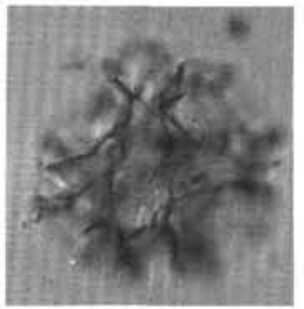

18

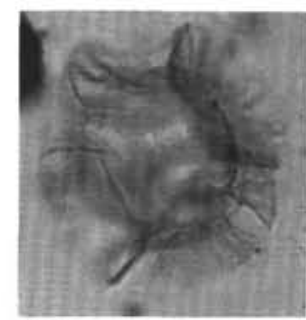

20

Plate 1. (All magnifications $\times 650$; photographs taken in normal transmitted light). UQP refers to the Université du Québec à Montréal, where all reference slides are curated. The alphanumeric code after the sample interval is the England Finder coordinate. 1,2. Impagidinium patulum in dorsal view; (1) dorsal surface, (2) ventral surface, Sample UQP-84-030-003P, 38-40 cm, J25/4. 3,4. Impagidinium paradoxum in ventral view: (3) dorsal surface, (4) ventral surface, Sample UQP-84-030-003TWC, 0-1 cm, P43/2. 5,6. Impagidinium aculeatum in ventral view: (5) dorsal surface, (6) ventral surface, Sample UQP-84-030-003P, 320-321 cm, M 42/2. 7-9. Impagidinium sphaericum in ventral view: (7) dorsal surface, (8) optical section, (9) ventral surface, Sample UQP-84-030-003P, 19-20 cm, D59/3. 10-12. Impagidinium sp. I in dorsal view: (10) dorsal surface, (11) optical section, (12) ventral surface, Sample UQP-112/4', 646B-36X-2, 71-76 cm, Y70/3. 13,14. Impagidinium strialatum: (13) dorso-lateral view, (14) optical section, Sample UQP-84-030-003P, 19-20 cm, G40/2. 15,16. Impagidinium cf. pallidum in ventral view: (15) dorsal surface, (16) ventral surface, Sample UQP-84-030-003P, 470-471 cm, S27/0. 17,18. Impagidinium japonicum in dorsal view: (17) dorsal surface, (18) ventral surface, Sample UQP-112/4', 646B-36X-2, 71-76 cm, C65/4. 19. Impagidinium velorum: optical section, orientation unknown, Sample UQP-112/4', 646B$36 \mathrm{X}, 2,71-76 \mathrm{~cm}, \mathrm{~J} 29 / 3$. 20. Impagidinium velorum: optical section, orientation unknown, Sample UQP-115/4, 646B-3BX-3, 53-56 cm, U69/3. 


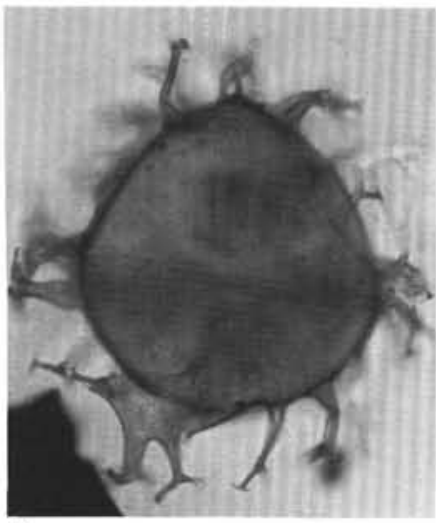

1

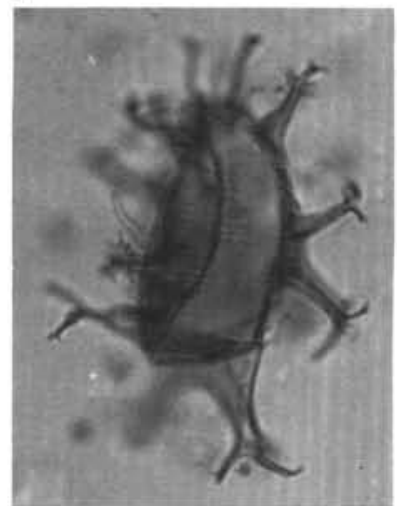

5

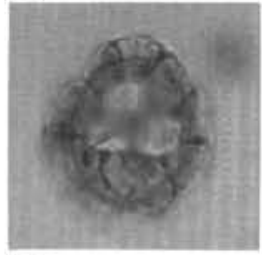

9

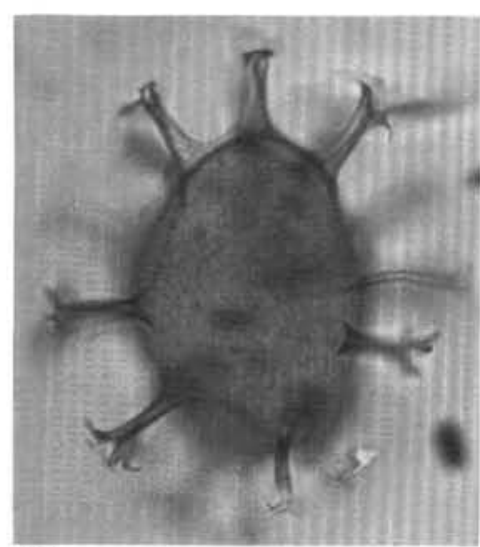

14

2

6

10
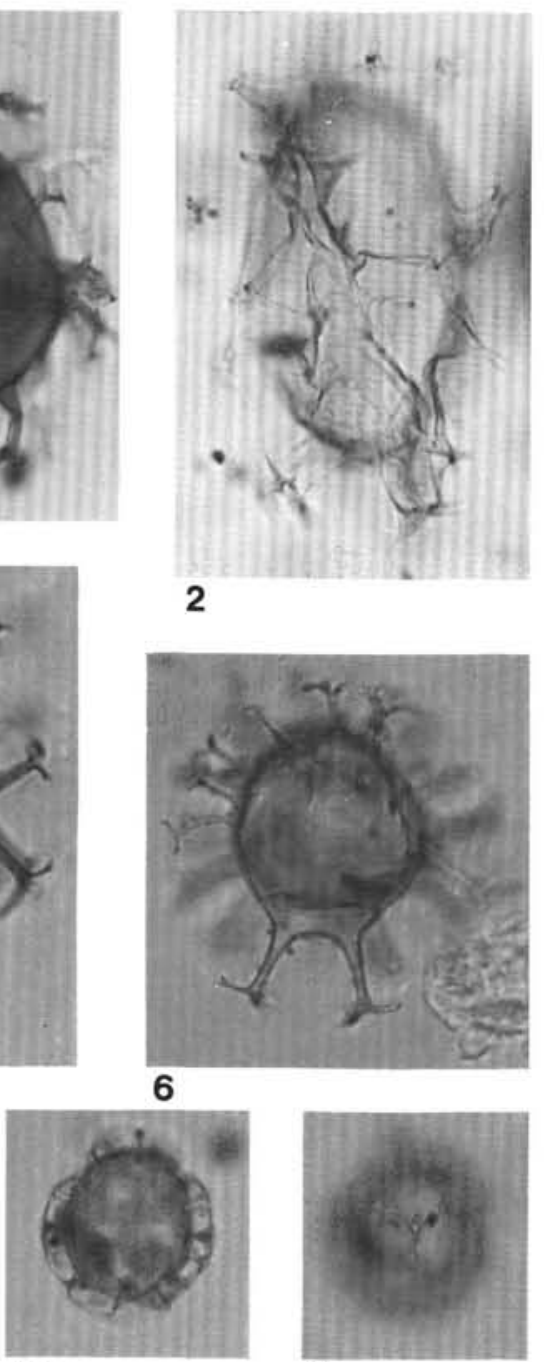

11

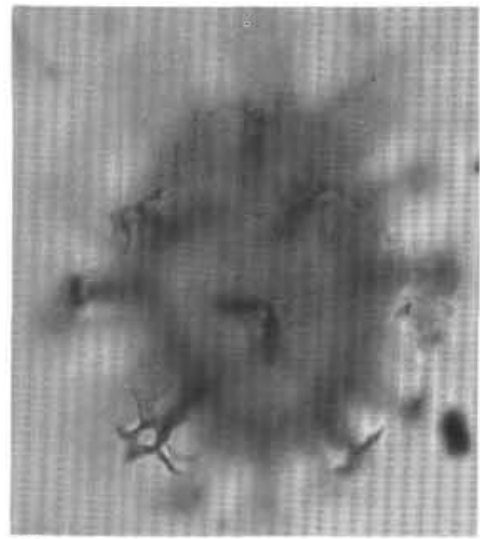

15

3

7

12

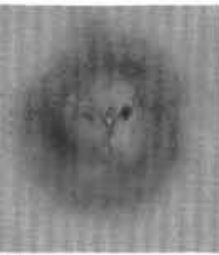

11
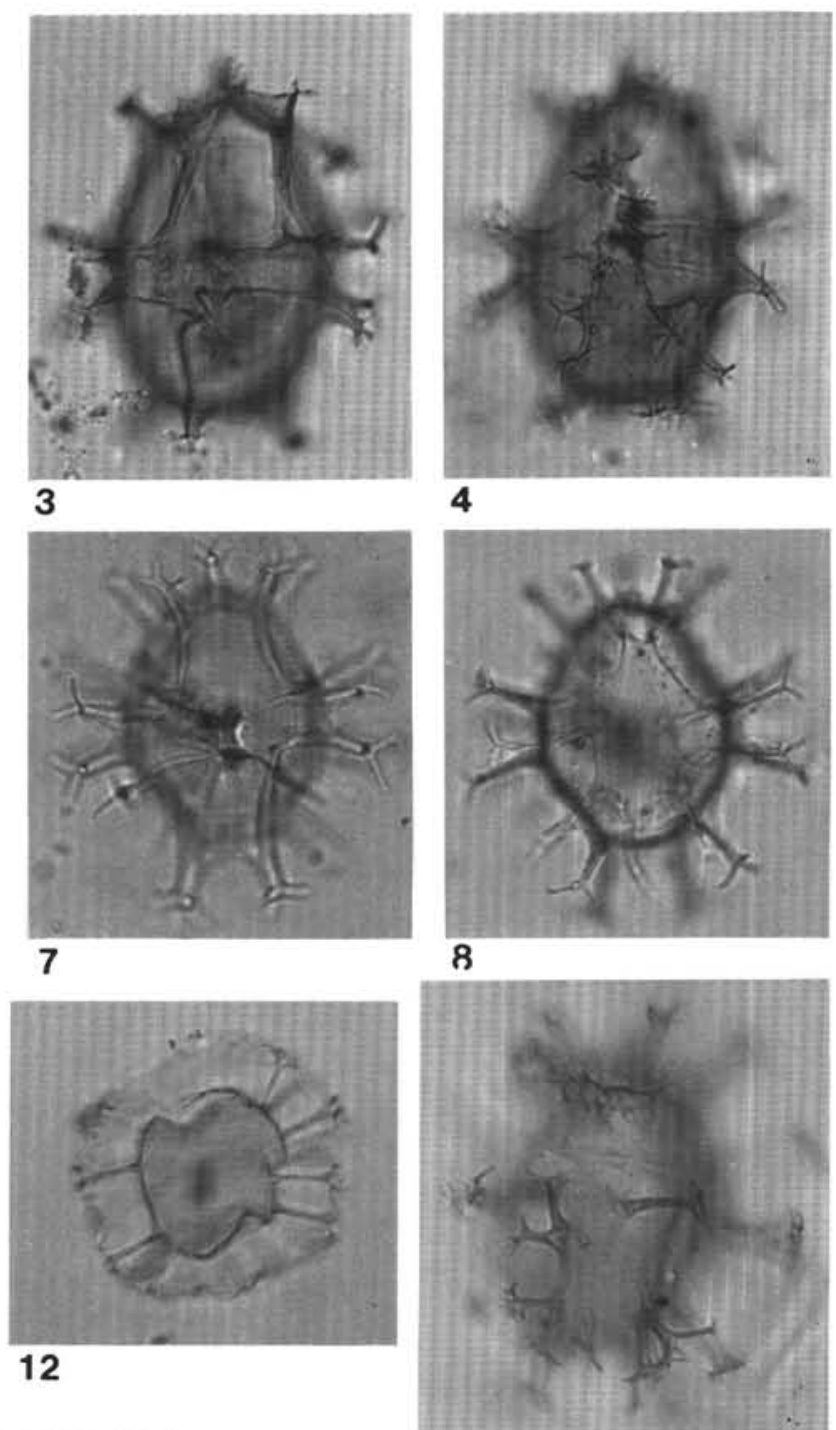

4

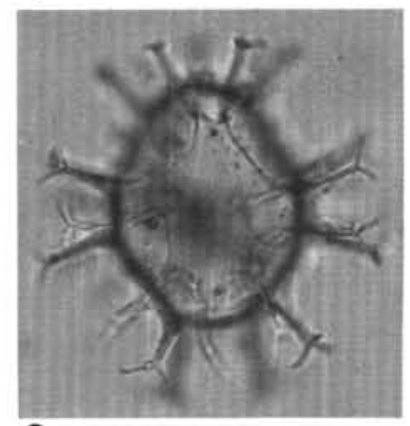

8

13

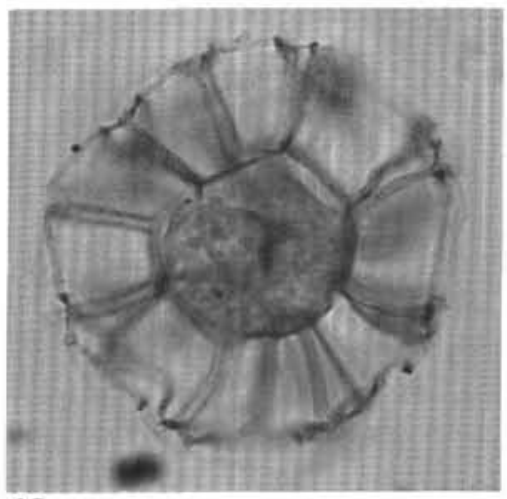

16

Plate 2. (All magnifications $\times 650$; photographs taken in normal transmitted light). UQP refers to the Université de Québec à Montréal, where all reference slides are curated. The alphanumeric code after the sample interval is the England Finder coordinate. 1. Spiniferites mirabilis: optical section, Sample UQP-138/6', 105-646B-2H-4, 18-20 cm, S49/4. 2. Spinerites elongatus in ventral view ( $S$. frigidus morphotype): ventral surface, Sample UQP-116/2, 105-646B-39X-1, 19-24 cm, S32/2. 3,4. Spiniferites elongatus in ventral view: (3) dorsal surface, (4) ventral surface, Sample UQP-138/6', 105-646B-2H-4, 18-20 cm, S32/2. 5. Achomosphaera ramulifera: optical section, Sample UQP-117/2, 105-646B-40X-1, 21-26 cm, T60/0. 6. Achomosphaera ramulifera: oblique antapical view, UQP-108/5, 105-646B-31X-4, 27-32 cm, O69/0. 7,8. Spiniferites ramosus in dorsal view: (7) dorsal surface, (8) ventral surface, Sample UQP-84-030-003P, 19-20 cm, U51/0. 9-11. Nematosphaeropsis sp. I: (9) dorsal surface, (10) optical section, (11) ventral surface, Sample UQP-97/6', 105-646B-21X-4, 17-22 cm, S55/0. 12. Nematosphaeropsis labyrinthea (gracile form): optical section, Sample UQP-142/3', 105-646B-3H-4, 126-128 cm, N38/3. 13. Achomosphaera andalousiensis: ventral view, Sample UQP-142/3', 105-646B-3H-4, 126-128 cm. 14,15. Achomosphaera andalousiensis: (14) optical section in lateral view, (15) focus on process tips, Sample UQP$142 / 3^{\prime}, 105-646 \mathrm{~B}-3 \mathrm{H}-4,126-128 \mathrm{~cm}, \mathrm{U} 69 / 4$. 16. Nematosphaeropsis labyrinthea (robust form): optical section, Sample UQP-139/3', 105-646B$2 \mathrm{H}-4,77-79 \mathrm{~cm}, \mathrm{~T} 50 / 2$. 

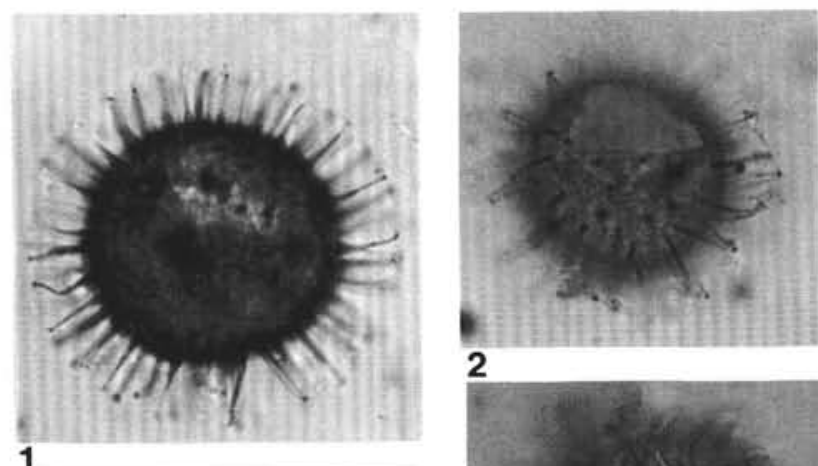

2

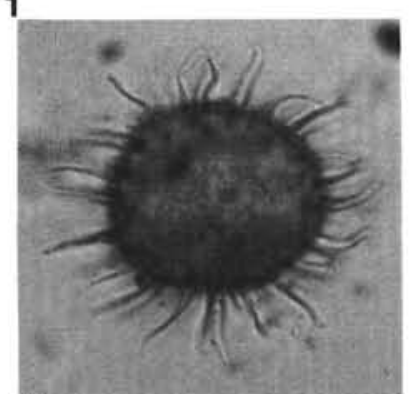

5

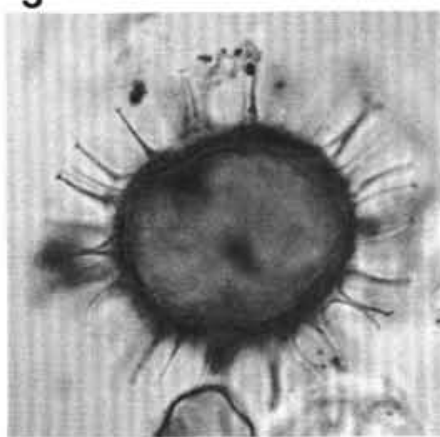

9

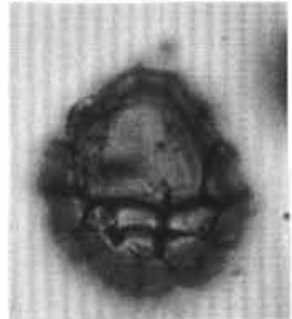

14

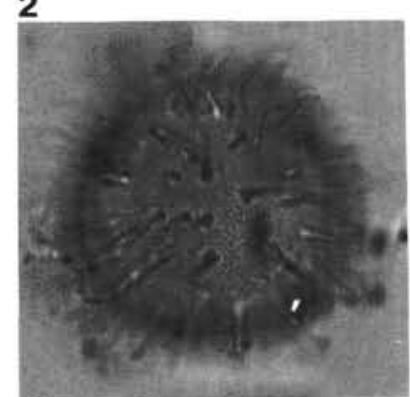

6

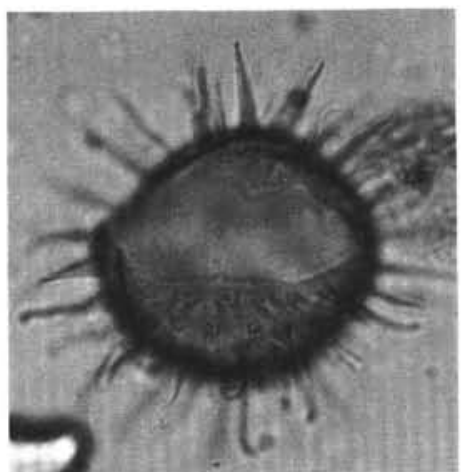

10

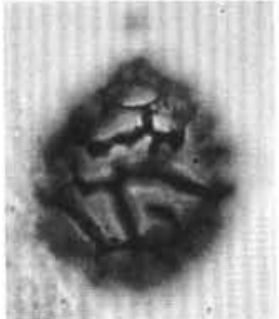

15

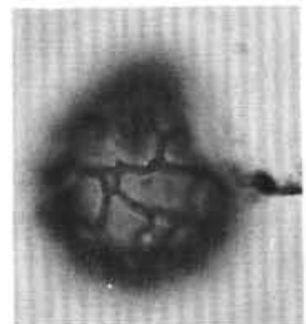

16

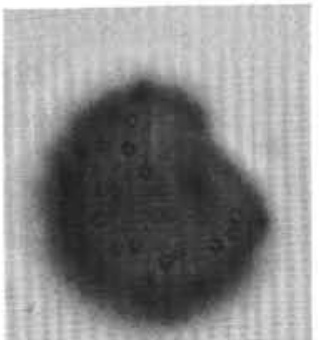

3

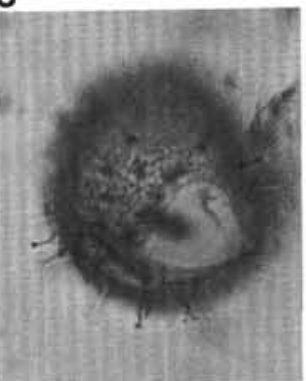

7

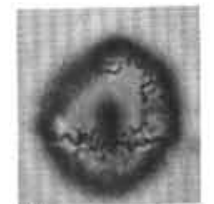

11

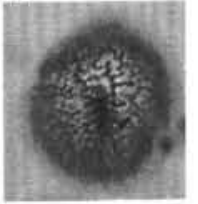

12

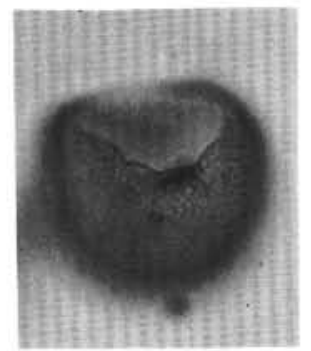

17
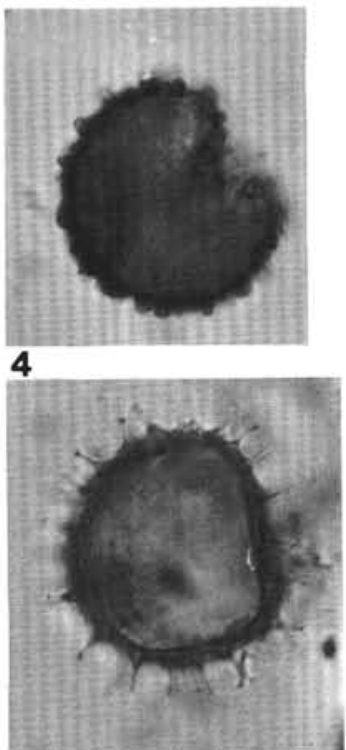

8

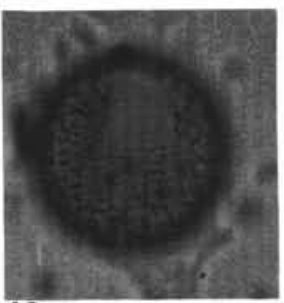

13

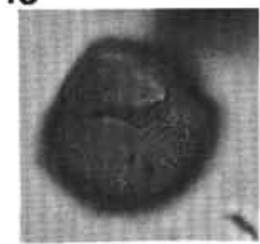

18

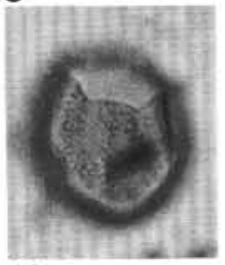

19

Plate 3. (All magnifications X650; photographs taken in normal transmitted light). UQP refers to the Université du Québec à Montréal, where all reference slides are curated. The alphanumeric code after the sample interval is the England Finder coordinate. 1. Operculodinium centrocarpum: optical section, Sample UQP-139/6', 105-646B-2H-4, 18-20 cm, Y27/0. 2. Operculodinium centrocarpum: dorsal surface, Sample UQP-139/3', 105-646B-2H-4, 77-79 cm, T70/1. 3,4. Operculodinium centrocarpum (form bearing short processes): (3) lateral view, (4) optical section, Sample UQP-139/6', 105-646B-2H-4, 18-20 cm W55/0. 5. Operculodinium longispinigerum: optical section, Sample UQP-108/5', 105-646B-31X-4, 39$44 \mathrm{~cm}, \mathrm{G} 26 / 0$. 6. Operculodinium longispinigerum: focus on the wall ornamentation, Sample UQP-112/4', 105-646B-36X-2, 71-76 cm, V67/3. 7,8. Opercuiodinium crassum: (7) oblique apical surface, (8) optical section, Sample UQP-116/2', 105-646B-39X-1, 19-24 cm, Q27/0. 9. Operculodinium crassum: optical section, Sample UQP-115/2', 105-646B-38X-1, 58-61 cm, V29/0. 10. Lingulodinium machaerophorum: dorsal surface, Sample UQP-84-030-003P, 526-527 cm, Q24/3. 11,12. ?Corrudinium sp. II: (11) dorsal surface, (12) ventral surface, Sample UQP-05/5, 105$646 \mathrm{~B}, 18 \mathrm{X}, \mathrm{CC}, \mathrm{Y} 48 / 2$. 13. ?Operculodinium sp. I: dorsal surface, Sample UQP-84-030-003P, 844-846 cm, V45/0. 14. Corrudinium sp. I: dorsal surface, Sample UQP-115/2', 105-646B-38X-1, 58-61 cm, S70/1. 15. Corrudinium sp. I: lateral view, Sample UQP-115/2', 105-646B-38X-1, 58$61 \mathrm{~cm}, \mathrm{R} 65 / 1$. 16. Corrudinium sp. I: lateral view, Sample UQP-115/2', 105-646B-38X-1, 58-61 cm, T67/1. 17. Batiacasphaera sphaerica: Sample UQP-115/2', 105-646B-38X-1, 58-61 cm, S67/0. 18. Batiacasphaera sphaerica: specimen with operculum, Sample UQP-115/2', 105-646B$38 \mathrm{X}-1,58-61 \mathrm{~cm}, \mathrm{U} 61 / 2$. 19. Batiacasphaera sphaerica: Sample UQP-115/2', 105-646B-38X-1, 58-61 cm, Q59/4. 


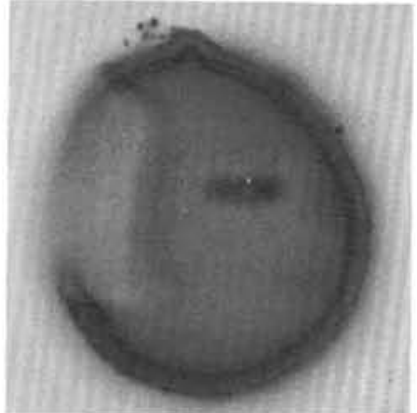

1

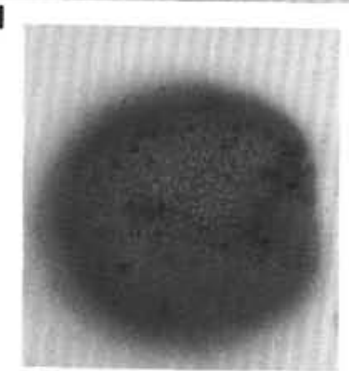

2

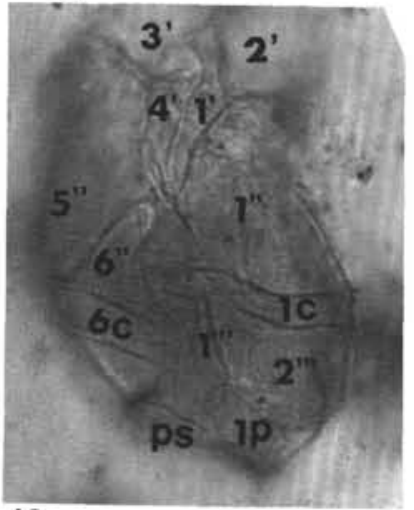

12

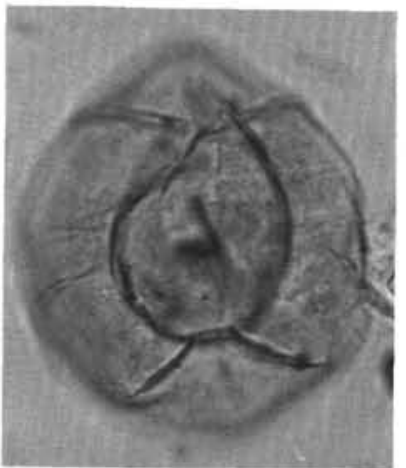

16

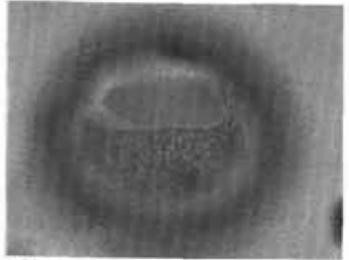

3

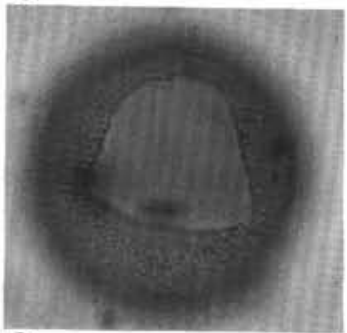

6

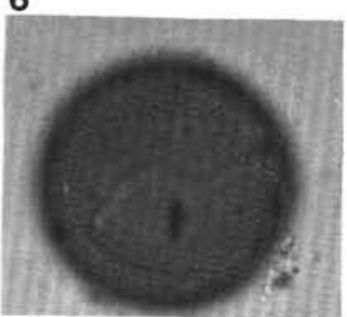

9

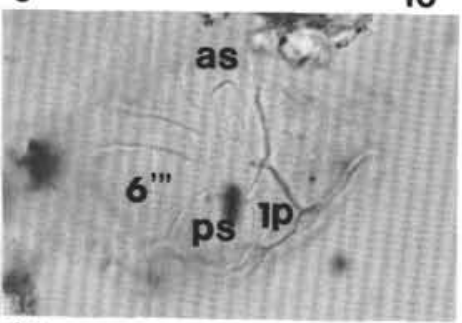

13

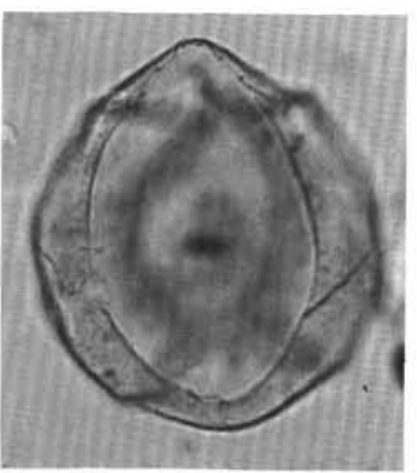

17

4

7

10
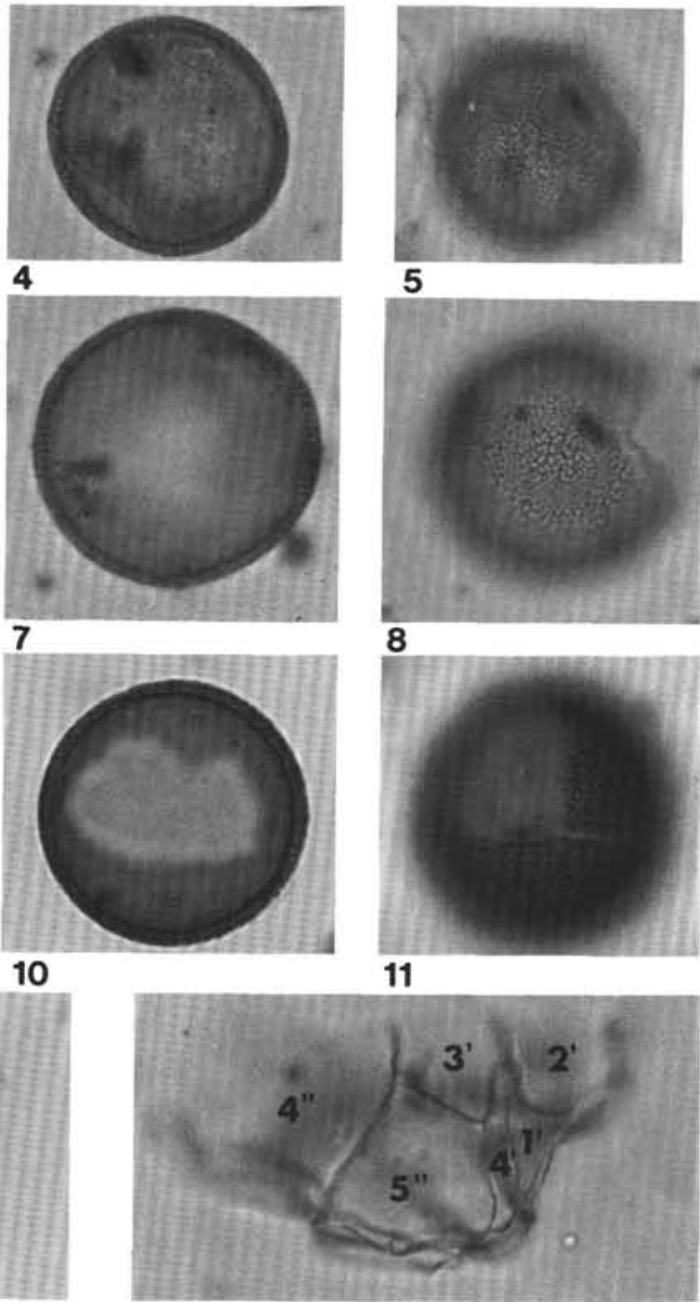

14

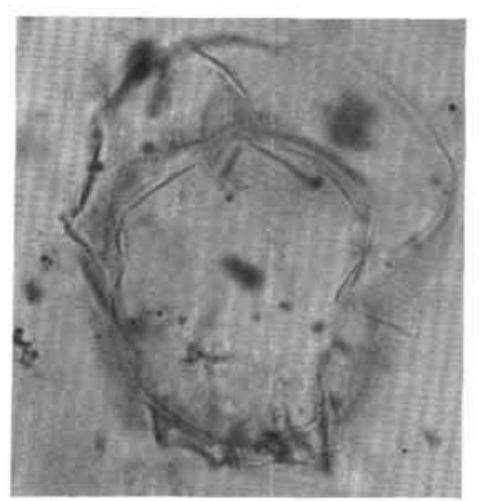

15

Plate 4. (All magnifications $\times 650$; photographs taken in normal transmitted light). UQP refers to the Université du Québec à Montréal, where all reference slides are curated. The alphanumeric code after the sample interval is the England Finder coordinate. 1. Filisphaera filifera: lateral view of specimen with a well developed apical boss, Sample UQP-94/4, 105-646B-13H-5, 20-25 cm, F52/0. 2. Filisphaera filifera: tangential view, Sample UQP-115/2', 105-646B-38X-1, 58-61 cm, L30/0. 3. Tectatodinium sp. I: dorsal surface, Sample UQP-108/5', 105-646B-31X-4, 27-32 cm, F53/ 0. 4. Tectatodinium sp. I: optical section, Sample UQP-108/5', 105-646B-31X-4, 27-32 cm, R51/1. 5. Tectatodinium sp. I: lateral view, focus on the wall ornamentation, Sample UQP-108/5', 105-646B-31X-4, 27-32 cm, R44/0. 6. Tectatodinium sp. II: dorsal surface, Sample UQP-97/6', 105-646B-21X4, 17-22 cm, T59/3. 7. Tectatodinium sp. II: optical section, Sample UQP-97/6', 105-646B-21X4, 17-22 cm, T59/3. 8. Tectatodinium sp. II: lateral view, focus on the wall ornamentation, Sample UQP-97/6', 105-646B-21X4, 17-22 cm, X27/2. 9. Bitectatodinium tepikiense: oblique apical surface, specimen with operculum, Sample UQP-138/6', 105-646B-2H-4, 18-20 cm, V40/1. 10. Bitectatodinium tepikiense: optical section, specimen with operculum free, Sample UQP-84-030-003P, 19-20 cm, W63/0. 11. Bitectatodinium tepikiense: dorsal surface, specimen with one (over two) archeopyle paraplate attached, Sample UQP-139/3', 105-646B-2H-4, 77-79 cm, Q42/2. 12. Invertocysta sp. I: ventral view, Sample UQP-112/3, 105-646B-36X-1, 82-87 cm, U52/0. 13. Invertocysta sp. I: focus on the parasulcus in ventral view, Sample UQP-112/2', 105-646B$35 \mathrm{X}-2,22-28 \mathrm{~cm}, \mathrm{U} 71 / 3$. 14. Invertocysta sp. I: apical view, Sample UQP-112/2', 105-646B-35X-2, 22-28 cm, E34/0. 15. Invertocysta sp. I: optical section, Sample UQP-113/4, 105-646B-36X-6, 114-119 cm, U49/0. 16,17. Invertocysta lacrymosa: (16) ventral surface, (17) dorsal surface, Sample UQP-108/5', 105-646B-31X-4, 27-32 cm, P22/2. 


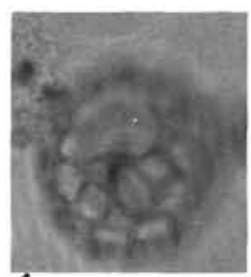

1

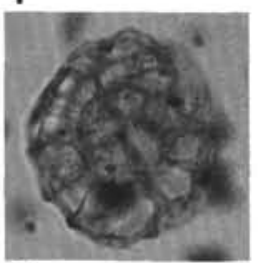

4
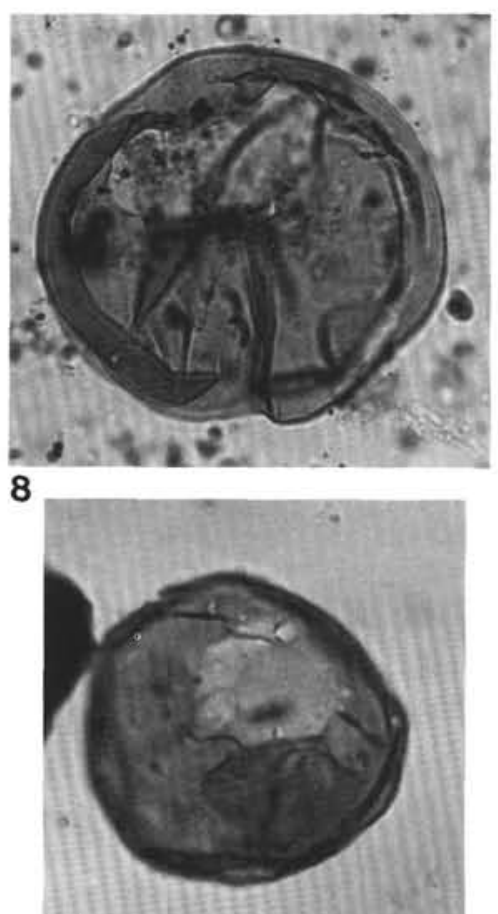

11

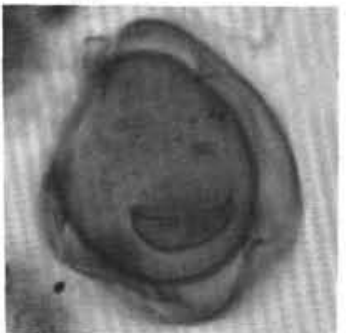

17

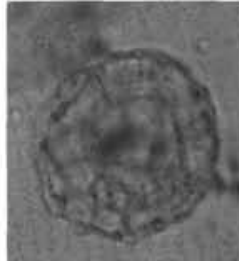

2

5

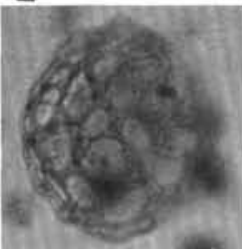

3

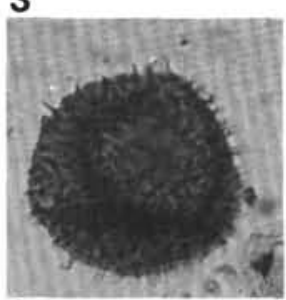

6

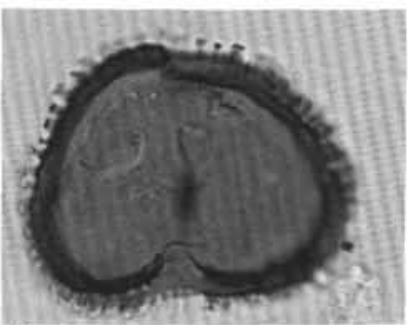

9

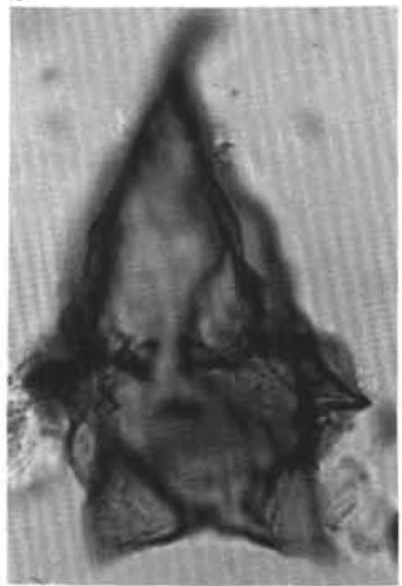

12

7
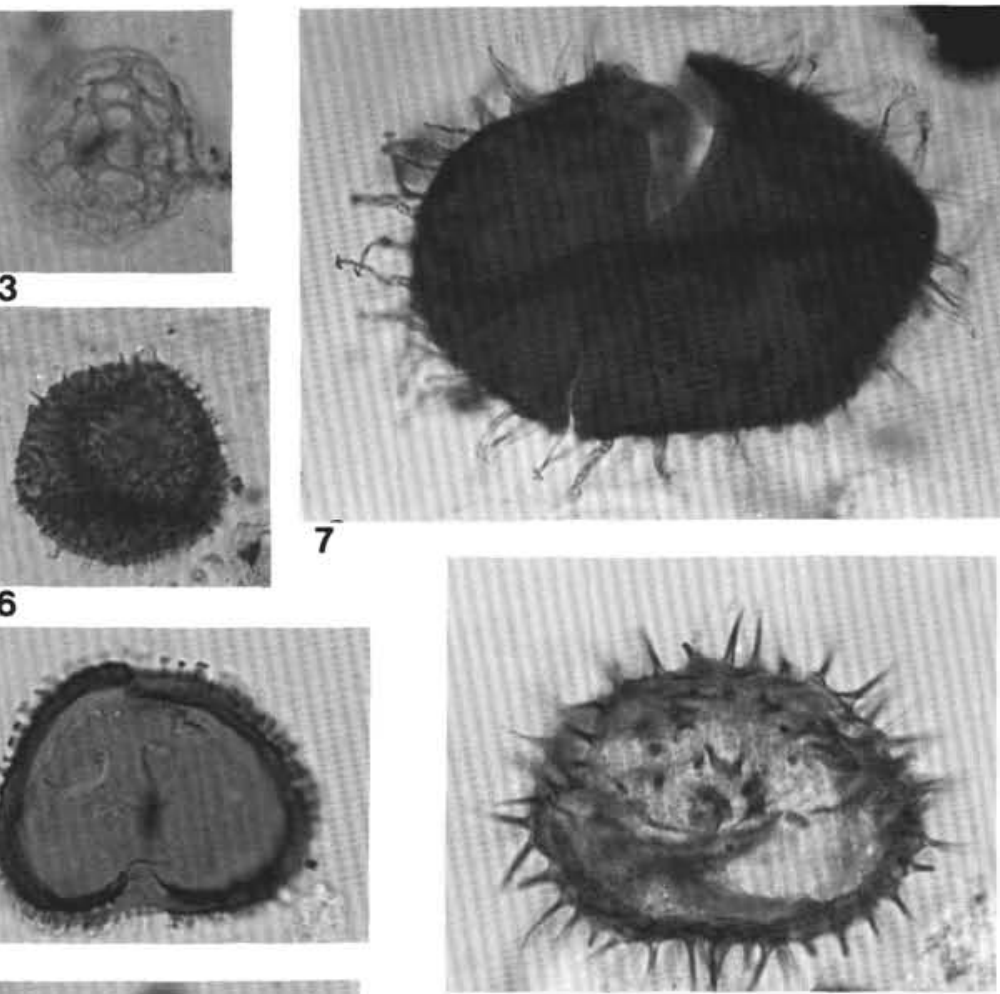

10

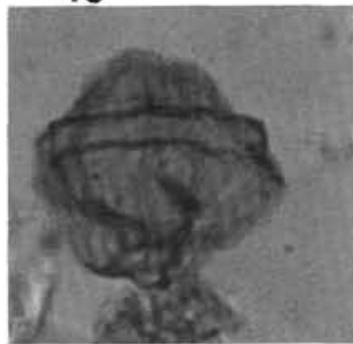

13

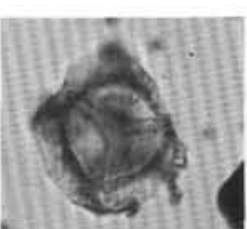

20

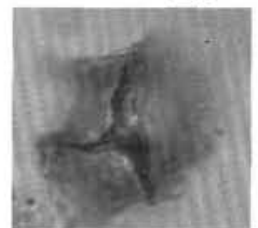

21

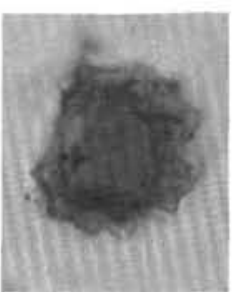

19

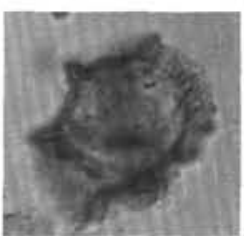

22

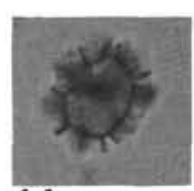

14

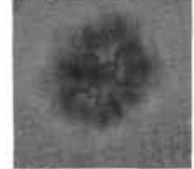

15

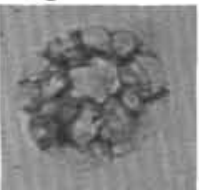

16

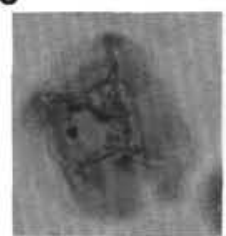

23

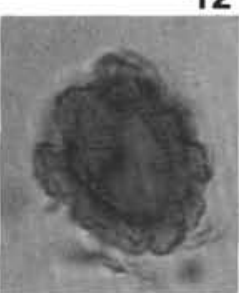

18

Plate 5. (All magnifications $\times 650$; photographs taken in normal transmitted light). UQP refers to the Université du Québec à Montréal, where all reference slides are curated. The alphanumeric code after the sample interval is the England Finder coordinate. 1-3. Cyst type I: (1) dorsal surface, (2) optical section, (3) ventral surface, Sample UQP-116/4', 105-646B-39X-3, 19-24 cm, U71/0. 4,5. Cyst type I: (4) optical section, (5) lateral view, Sample UQP-07/7, 105-646B-39X,CC, P36/0. 6. Multispinula minuta: Sample UQP-84-030-003TWC, 0-1 cm, K63/3. 7. Xandarodinium variabile: Sample UQP-108/5', 105-646B-31X-4, 27-32 cm, R46/1. 8. Selenopemphix nephroides: Sample UQP-35/1, 105-647A-7R-1, 3-8 cm, X39/0. 9. Selenopemphix cf. armata: Sample UQP-116/3, 105-646B-39X-2, 19-24 cm U39/4. 10. Multispinula quanta: Sample UQP-139/3', 105-646B-2H-4, 77-79 cm, V65/3. 11. Brigantedinium simplex: Sample UQP-116/4', 105-646B-39X-3, 19-24 cm, D52/2. 12. Lejeunecysta cf. fallax: Sample UQP-115/2, 105-646B-38X-1, 58-61 cm. R36/4. 13. Lejeunecysta paratenella: Sample UQP-116/4', 105-646B-39X-3, 19-24 cm, G71/3. 14,15. Cymatiosphaera sp. I: Sample UQP-112/2', 105-646B-35X-2, 22-28 cm, E37/2. 16. Cymatiosphaera sp. I: Sample UQP-116/4', 105-646B-39X-3, 19-24 cm, P45/2. 17. Ataxidinium choanum: lateral view, Sample UQP-138-6', 105-646B-2H-4, 18-20 cm, M38/2. 18. Incertae sedis II: Sample UQP-108/5', 105-646B-31X-4, 27-32 cm, V56/2. 19. Incertae sedis II: Sample UQP-112/4', 105-646B-36X-2, 71-76 cm, F65/3. 20,23. Incertae sedis I: Sample UQP-07/3, 105-646B-34X,CC, Y43/1. 21,22. Incertae sedis I: Sample UQP-108/5', 105-646B-31X-4, 27-32 cm, W24/1. 